Published in Dalton Transactions 2020,49, 12731-12741

\title{
Metal coordination of phosphoniocarbynes
}

\begin{abstract}
Chee S. Onn, Anthony F. Hilla,* and Angus Olding
Heterobi- and tetrametallic phosphoniocarbyne bridged complexes $\left[\mathrm{WAu}\left(\mu-\mathrm{CPMe}{ }_{2} \mathrm{Ph}\right) \mathrm{Cl}(\mathrm{CO})_{2}\left(\mathrm{Tp}^{*}\right)\right]^{+}\left(\mathrm{Tp}^{*}=\right.$ hydrotris $(3,5-$ dimethylpyrazol-1-yl)borate), $\left[\mathrm{W}_{2} \mathrm{Cu}_{2}\left(\mu-\mathrm{CPMe}_{2} \mathrm{Ph}\right)_{2}(\mu-\mathrm{Cl})_{2}(\mathrm{CO})_{4}\left(\mathrm{Tp}^{*}\right)_{2}\right]^{2+}$ and $\left[\mathrm{WPt}\left(\mu-\mathrm{CPMe} \mathrm{Ph}_{2}\right)(\mathrm{COD})(\mathrm{CO})_{2}\left(\mathrm{Tp}^{*}\right)\right]^{+}(\mathrm{COD}=1,5-$ cyclo-octadiene) arise from the reactions of the mononuclear terminal phosphoniocarbyne $\left[\mathrm{W}\left(\equiv \mathrm{CPMe} \mathrm{PPh}_{2}(\mathrm{CO})_{2}\left(\mathrm{Tp}^{*}\right)\right] \mathrm{PF}_{6}\right.$ with $[\mathrm{AuCl}(\mathrm{THT})]\left(\mathrm{THT}=\right.$ tetrahydrothiophene), $\left[\mathrm{CuCl}\left(\mathrm{SMe}_{2}\right)\right]$ and $\left[\mathrm{Pt}(\mathrm{nbe})_{3}\right](\mathrm{nbe}=$ norbornene) in the presence of COD. The COD ligand in $\left[\mathrm{WPt}\left(\mu-\mathrm{CPMe} \mathrm{P}_{2} \mathrm{Ph}\right)(\mathrm{COD})(\mathrm{CO})_{2}\left(\mathrm{Tp}^{*}\right)\right]^{+}$is labile and readily replaced by isonitriles to provide $[\mathrm{WPt}(\mu-$ $\left.\left.\mathrm{CPMe}_{2} \mathrm{Ph}\right)(\mathrm{CNR})_{2}(\mathrm{CO})_{2}\left(\mathrm{Tp}^{*}\right)\right]^{+}\left(\mathrm{R}={ }^{\mathrm{t}} \mathrm{Bu}, \mathrm{C}_{6} \mathrm{H}_{2} \mathrm{Me}_{3}-2,4,6\right)$ with retention of the tungstaplatinacyclopropene core, the bonding within which was computationally interrogated.
\end{abstract}

\section{Introduction}

Terminal phosphoniocarbyne complexes $\left[\mathrm{L}_{n} M \equiv C P R_{3}\right]$ remain somewhat rare due to the lack of general synthetic routes. The first example, $\left[\mathrm{W}_{2}(\equiv \mathrm{CPMe})_{2} \mathrm{Cl}_{4}\left(\mathrm{PMe}_{3}\right)_{4}\right]\left[\mathrm{AlCl}_{4}\right]_{2}$ (Chart 1), was observed by Schrock to arise from the reaction of $\left[\mathrm{W}(\equiv \mathrm{CH}) \mathrm{Cl}\left(\mathrm{PMe}_{3}\right)_{4}\right]$ with $\mathrm{C}_{2} \mathrm{Cl}_{6} / \mathrm{Al}_{2} \mathrm{Cl}_{6} .{ }^{1}$ Hillhouse subsequently observed a novel cleavage of carbon suboxide $\mathrm{C}_{3} \mathrm{O}_{2}$ or $\mathrm{Ph}_{3} \mathrm{P}=\mathrm{C}=\mathrm{C}=\mathrm{O}$ by $\left[\mathrm{WCl}_{2}\left(\mathrm{PMePh}_{2}\right)_{4}\right]$ to afford, respectively, $\left[\mathrm{WCl}_{2}\left(\equiv \mathrm{CPMePh}_{2}\right) \mathrm{Cl}_{2}(\mathrm{CO})\left(\mathrm{PMePh}_{2}\right)_{2}\right]$ or $\left[\mathrm{WCl}_{2}\left(\equiv \mathrm{CPPh}_{3}\right) \mathrm{Cl}_{2}(\mathrm{CO})-\right.$ $\left.\left(\mathrm{PMePh}_{2}\right)_{2}\right]^{2}$

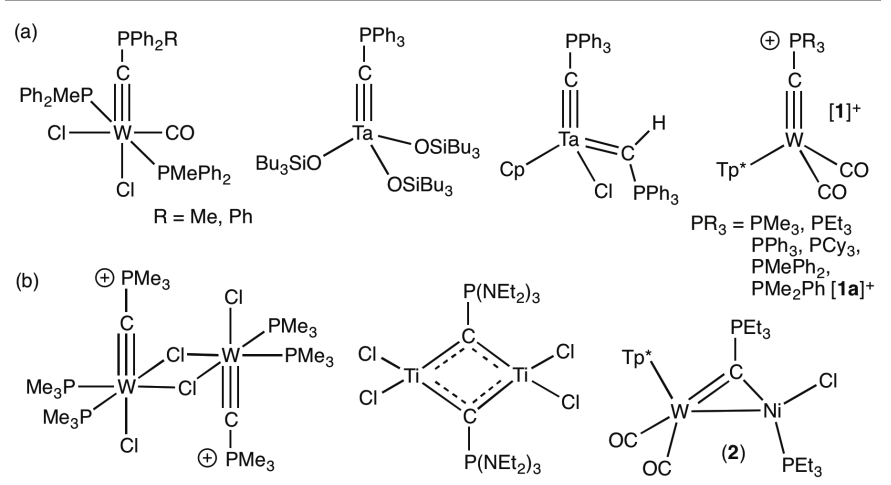

Chart 1. Exemplary (a) mononuclear and (b) binuclear phosphoniocarbynes.

An approach that promises some degree of general applicability was developed by Sundermeyer and $\mathrm{Li}^{3}{ }^{3}$ being based on earlier observations by Schmidbauer ${ }^{4}$ and involves the reactions of high-valent transition-metal chlorides with phosphorus methylides, in which the methylide serves as both nucleophile and dehydrohalogenation agent. None of these reports have been followed by studies of the ligand-based reactivity, however Templeton has demonstrated that

\footnotetext{
a. Research School of Chemistry, Australian National University, Canberra,

Australian Capital Territory, ACT 2601, Australia.

*Corresponding author. E-mail: a.hill@anu.edu.au
}

phosphoniocarbynes have considerable synthetic versatility. ${ }^{5}$ The salts $\left[\mathrm{W}\left(\equiv \mathrm{CPR} \mathrm{R}_{3}\right)(\mathrm{CO})_{2}\left(\mathrm{Tp}^{*}\right)\right] \mathrm{PF}_{6}\left(\mathrm{PR}_{3}=\mathrm{PMe}_{3}, \mathrm{PEt}_{3}, \mathrm{PPh}_{3}, \mathrm{PCy}_{3}\right.$, $\mathrm{PMe}_{2} \mathrm{Ph}[1 \mathrm{a}] \mathrm{PF}_{6} ; \mathrm{Tp}^{*}=$ hydrotris(dimethylpyrazolyl)borate) arise from the reactions of $\left[\mathrm{W}(\equiv \mathrm{CX})(\mathrm{CO})_{2}\left(\mathrm{Tp}^{*}\right)\right]\left(\mathrm{X}=\mathrm{Cl}\right.$, $\left.{ }^{5 a} \mathrm{SMe}^{5 b}\right)$ and the phosphine of choice or methylation of the phosphinocarbyne $\left[\mathrm{W}(\equiv \mathrm{CPPh})(\mathrm{CO})_{2}\left(\mathrm{Tp}^{*}\right)\right]\left(\mathrm{PR}_{3}=\mathrm{PMePh}_{2}{ }^{6}\right)$ and they react with a range of nucleophiles either at the metal, a carbonyl co-ligand or ultimately at the phosphoniocarbyne carbon. ${ }^{5}$ Binuclear phosphoniocarbynes are far rarer and until recently were limited to Schrock's halide bridged dimer, ${ }^{1}$ Schmidbauer's carbyne bridged dimer $\left[\mathrm{Ti}_{2}\left\{\mu-\mathrm{CP}\left(\mathrm{NMe}_{2}\right)_{3}\right\}_{2} \mathrm{Cl}_{4}\right]$ (from $\mathrm{TiCl}_{4}$ and $\left.\mathrm{H}_{2} \mathrm{CP}\left(\mathrm{NMe}_{2}\right)_{3}\right)^{4}$ and the heterobimetallic complex $\left[\mathrm{WNi}\left(\mu-\mathrm{CPEt}_{3}\right) \mathrm{Cl}(\mathrm{CO})_{2}\left(\mathrm{PEt}_{3}\right)\left(\mathrm{Tp}^{*}\right)\right]$ (2) which is formed upon rearrangement of the $\mu$-carbido complex [WNi( $\mu$ C) $\left.\mathrm{ClCO})_{2}\left(\mathrm{PEt}_{3}\right)\left(\mathrm{Tp}^{*}\right)\right] .{ }^{7}$ Very recently, phosphoniocarbynes have assumed some practical relevance when the complexes $\left[\mathrm{WPd}\left(\mu-\mathrm{CPPh}_{3}\right) \operatorname{Br}(\mathrm{CO})_{2}\left(\mathrm{PPh}_{3}\right)_{n}\left(\mathrm{Tp}^{*}\right)\right](\mathrm{n}=0,1)$ were identified $^{8}$ as non-productive tangents to the catalytic cycle for palladium mediated cross coupling reactions involving the bromocarbyne complex $\left[\mathrm{W}(=\mathrm{CBr})(\mathrm{CO})_{2}\left(\mathrm{Tp}^{*}\right)\right](3) .{ }^{9}$

Given the dearth of bimetallic phosphoniocabyne complexes $^{10}$ we have therefore addressed their strategic synthesis, employing Stone's bridge-assisted metal-metal bond construction approach. ${ }^{11}$ Herein we report the first heterobimetallic examples involving tungsten and copper, gold or platinum.

\section{Results and Discussion}

Templeton's salt [1a]PF 6 was chosen for proof of concept for two reasons. Firstly, the $\mathrm{PMe}_{2} \mathrm{Ph}$ group has a comparatively small cone angle $\left(122^{\circ}\right), 12$ which is likely to ameliorate steric interference. Secondly, the $\mathrm{PMe}_{2}$ group presents further structural information in the event that subsequent reactions lower the molecular symmetry rendering the 'reporter' methyl groups magnetically inequivalent and diastereotopic. It transpired, however, that all the compounds described herein had either ground-state or thermally accessible $C_{\mathrm{s}}$-symmetric 
conformers. The salt [1a]PF 6 was prepared from 3, $\mathrm{PMe}_{2} \mathrm{Ph}$ and $\mathrm{NaPF}_{6}$ in acetonitrile in essentially quantitative yield via a minor modification (Scheme 1) of Templeton's reported synthesis from $\left[\mathrm{W}(\equiv \mathrm{CCl})(\mathrm{CO})_{2}\left(\mathrm{Tp}^{*}\right)\right] .{ }^{5 b}$ This does not represent an improvement but simply reflects the local availability of $\mathbf{3}$ from our other studies.

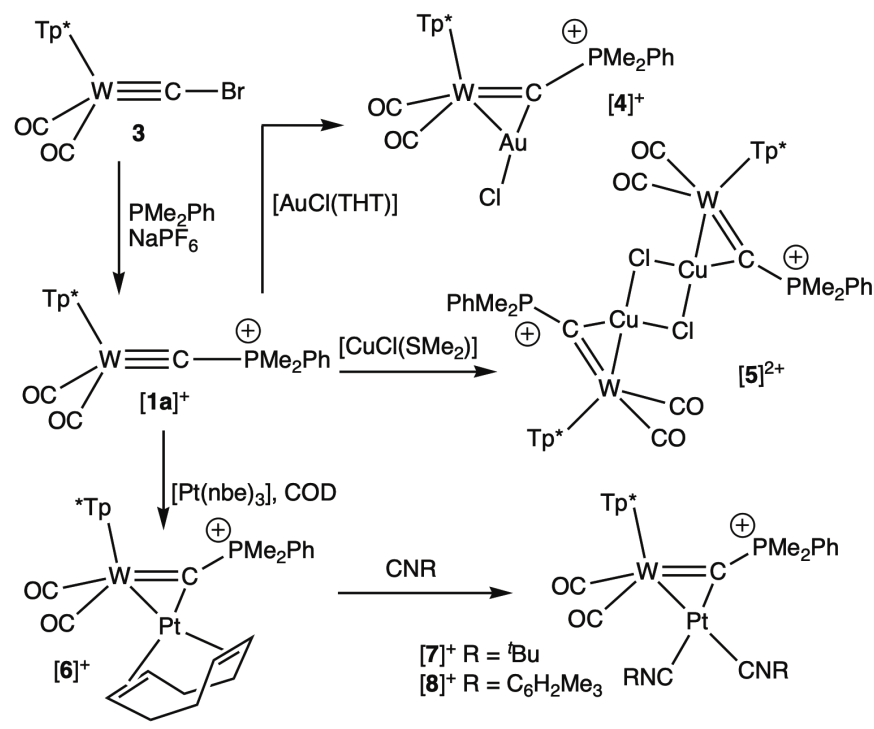

Scheme 1. Synthesis of bi- and tetrametallic phosphoniocarbyne complexes.

The frontier orbitals of interest (DFT: $\omega B 97 X-D / 6-$ $31 G * / L a n L 2 D \zeta / G a s-p h a s e)$ for the simplified model complex $\left[\mathrm{W}\left(\equiv \mathrm{CPMe}_{3}\right)(\mathrm{CO})_{2}(\mathrm{Tp})\right]^{+}$(WP, Tp = hydrotris(pyrazolyl)borate) are illustrated in Figure 1, alongside those for the isoelectronic analogues $\left[\mathrm{W}\left(=\mathrm{CAMe}_{3}\right)(\mathrm{CO})_{2}(\mathrm{Tp})\right]^{+}\left(\mathrm{A}=\mathrm{Si} \mathbf{W S i}, \mathrm{C} \mathrm{WC}, \mathrm{N}^{+} \mathbf{W N}\right)$ for comparative purposes. The $\mathrm{Tp}^{*}$ complex with $\mathrm{A}=\mathrm{C}$ is plausible and for $\mathrm{A}=\mathrm{Si}$ is known,13a,b and whilst no ammoniocarbynes have been reported $\left(A=N^{+}\right)$, the known iminium carbyne $\left[\mathrm{Mo}(\equiv \mathrm{C}-\mathrm{DMAP})(\mathrm{CO})_{2}\left(\mathrm{Tp}^{*}\right)\right]^{+} \quad$ (DMAP $=\mathrm{N}, \mathrm{N}-$ dimethylaminopyridine $)^{13 c}$ would imply that such ligands were plausible. One might entertain a canonical description involving $\mathrm{W}=\mathrm{C}$ and $\mathrm{P}=\mathrm{C}$ double bonds, thereby placing a positive charge on tungsten (consistent with the high $v_{\text {co }}$ frequencies), however this is not borne out by computational interrogation, with none of the 20 highest molecular orbitals involving appreciable $\mathrm{C} \pi-\mathrm{P} \pi$ overlap. This delivers Löwdin bond orders of 2.50 and 1.09 for the $\mathrm{W} \equiv \mathrm{C}$ and $\mathrm{C}-\mathrm{P}$ bonds, respectively, and a natural charge on tungsten of +1.17 , values that are not dissimilar to those for the ammoniocarbyne $\left(A=N^{+}: 2.52,1.04\right.$ and +1.09$)$ or indeed the simple neopentylidyne $(\mathrm{A}=\mathrm{C}: 2.46,1.05$ and +0.96) or silylcarbyne $(\mathrm{A}=\mathrm{C}: 2.59,0.92$ and +0.99) analogues. Accordingly, it is best to consider the positive charge to be primarily located at phosphorus $(+1.63)$. The $\mathrm{W}-\mathrm{C}$ bond lengths are rather similar across the series (1.799 - $1.809 \AA$ ) with the variance being less than the typical limits of crystallographic precision. The trans influence of carbyne ligands in complexes of the form $\left[M(\equiv C R)(C O)_{2}(L)\right](L=T p, T p *)$ has been quantified with the singular parameter $\mathbf{T R}$ which is the ratio of the $\mathrm{M}-\mathrm{N}$ bond length trans to the carbyne ligand $v s$ the mean of the remaining two $\mathrm{M}-\mathrm{N}$ bonds. ${ }^{14}$ For all members of the series, a pronounced trans influence is noted ( $T R=1.043 \mathrm{WC}, 1.068 \mathrm{WSi}$,
1.025 WN, 1.041 WP) and in each case replacement of the $2 p$ element by the heavier more electropositive $3 p$ element from the same group results in a marginal increase in this influence. The frequencies of the carbonyl-associated infrared data for the series (1994, 1927 WC, 2002, 1936 WSi, 2036, 1971 WN; 2041, $1979 \mathrm{~cm}^{-1}$ WP) are impacted most by the overall charge of the complex (cationic WN and WP $c f$. neutral WC and WSi), whilst the modes associated predominantly with $W \equiv C$ stretching (1108 WC, 1158 WSi, 1180 WN, $1192 \mathrm{~cm}^{-1} \mathbf{W P}$ ) also appear to higher frequencies for the charged complexes with the expected increase in relative intensity due to $\mathrm{C}-\mathrm{N}$ and $\mathrm{C}-\mathrm{P}$ oscillator polarity ( $c f$. C-C and C-Si).

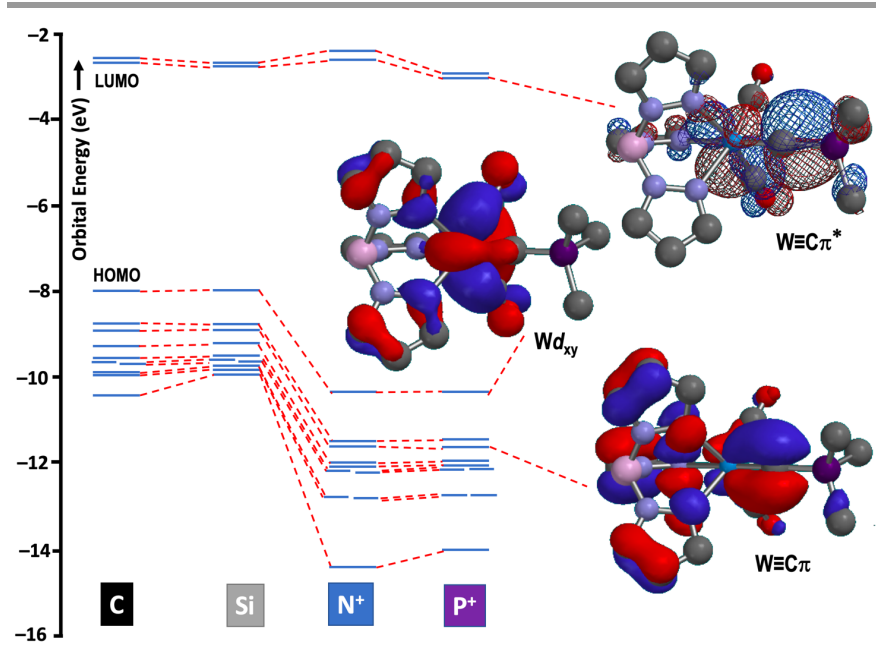

Figure 1. Frontier orbitals of interest (DFT: $\omega B$ B7X-D/B3LYP/LANL2D $\zeta$ ) for the isoelectronic complexes $\left[\mathrm{W}\left(\equiv \mathrm{CAR}_{3}\right)(\mathrm{CO})_{2}\left(\mathrm{Tp}^{*}\right)\right]^{+}\left(\mathrm{A}=\mathrm{C} \mathbf{W C}, \mathrm{Si} \mathbf{W S i}, \mathrm{N}^{+} \mathbf{W N}, \mathrm{P}^{+} \mathbf{W P}\right.$; isovalue $=0.032 ; \mathrm{W}-\mathrm{C}$ as $z$-axis $)$.

In the context of coordination of the $\mathrm{W} \equiv \mathrm{C}$ bond to extraneous metal centres, ${ }^{11}$ the isolobal analogy ${ }^{11 b}$ with alkynes allows a simple Dewar-Chatt-Duncanson description of bonding within the resulting dimetalla-cyclopropenes. ${ }^{15}$ Accordingly, the frontier orbitals of interest are the occupied $\mathrm{W} \equiv \mathrm{C} \pi$ (HOMO-1,2) and empty $\mathrm{W} \equiv \mathrm{C} \pi *$ (LUMO, LUMO+1) orbitals associated with the $\mathrm{W} \equiv \mathrm{C}$ bond (Figure 1). ${ }^{16}$ The latter differ little across the series, whilst for the onium examples $\left(A=N^{+}, P^{+}\right)$the $W \equiv C \pi$ orbitals are significantly stabilised such that upon coordination as a 'ligand' the $\mathrm{W} \equiv \mathrm{CPMe}_{3}$ unit will be a comparable $\pi$-acceptor but far poorer donor to the appended metal centre than are conventional carbynes $(\mathrm{A}=\mathrm{C}, \mathrm{Si})$.

Aurous halides have a demonstrated proclivity for addition to metal-carbon multiple bonds, ${ }^{17}$ and accordingly the reaction of [1] $\mathrm{PF}_{6}$ with $[\mathrm{AuCl}(\mathrm{THT})]$ (THT = tetrahydrothiophene) was investigated and found to rapidly provide the bimetallic salt $\left[\mathrm{WAu}\left(\mu-\mathrm{CPMe}{ }_{2} \mathrm{Ph}\right) \mathrm{Cl}(\mathrm{CO})_{2}\left(\mathrm{Tp}^{*}\right)\right]$ [4]PF 6 (Scheme 1, Table 1, Figure 2 ) in excellent yield. Purification by chromatography was required, after which the product was found to form an airstable, red solid. The complex however rapidly degrades in solution, decomposing within four hours even with the exclusion of oxygen and light. 
Table 1. Selected spectroscopic data for phosphoniocarbyne complexes $\left[\mathrm{W}\left(\mathrm{CPMe}_{2} \mathrm{Ph}\right)(\mathrm{CO})_{2}\left(\mathrm{Tp}^{*}\right) \mathrm{ML}_{n}\right]^{+}$.

$\begin{array}{rllllrll}\mathbf{M L}_{\mathrm{n}} & \boldsymbol{\delta}_{\mathrm{c}} & { }^{1} \boldsymbol{J}_{\mathrm{PC}}{ }^{a} & \boldsymbol{1}_{\mathrm{Wc}} & \boldsymbol{\delta}_{\mathrm{P}} & { }^{2} J_{\mathrm{WP}} & \boldsymbol{\delta}_{\mathrm{Pt}} & \boldsymbol{V}_{\mathrm{co}}{ }^{\boldsymbol{b}} \\ & \mathrm{ppm} & \mathrm{Hz} & \mathrm{Hz} & \mathrm{ppm} & \mathrm{Hz} & \mathrm{ppm} & \mathrm{cm}^{-1}\end{array}$

\begin{tabular}{|c|c|c|c|c|c|c|c|}
\hline$[1 \mathbf{a}]^{+}$ & $-c$ & 246.9 & n.r. & 205 & 13.3 & $165-$ & 2022,1935 \\
\hline$[4]^{+} \mathrm{AuCl}$ & 233.9 & 32 & n.i. & 29.0 & 96 & - & 2037,1961 \\
\hline$[5]^{2+} \mathrm{CuCl}^{d}$ & $e$ & $e$ & n.i. & 26.1 & & - & 2024, 1947 \\
\hline$[6]+\operatorname{Pt}(C O D)$ & 272.8 & 10 & 194 & 14.2 & 71 & -3587 & 2037,1960 \\
\hline$[7]^{+} \mathrm{Pt}\left(\mathrm{CN}^{t} \mathrm{Bu}\right)_{2}$ & $269.6^{f}$ & 14 & $n . i$ & 17.4 & 69 & -3953 & $1934,1846^{g}$ \\
\hline$[8]^{+} \mathrm{Pt}(\mathrm{CNMes})_{2}$ & 270.8 & 14 & n.i. & 18.7 & 62 & -3863 & $1941,1853^{h}$ \\
\hline
\end{tabular}

${ }^{a}$ Measured in $\mathrm{CDCl}_{3}$. ${ }^{b}$ Measured in $\mathrm{CH}_{2} \mathrm{Cl}_{2}$. ${ }^{\text {cData }}$ from reference $5 \mathrm{~b}$. ${ }^{d} \mathrm{Chloride}-$ bridged dimer. ${ }^{e}$ Not unequivocally identified. ${ }^{f} J_{\mathrm{PtC}}=801 \mathrm{~Hz} .{ }^{g} \mathrm{~V}_{\mathrm{CN}}=190,2157 \mathrm{~cm}^{-1}$. ${ }^{h} v_{\mathrm{CN}}=2164,2126 \mathrm{~cm}^{-1}$. Abbreviations: $\mathrm{COD}=1,5$-cyclooctadiene, $\mathrm{Mes}=\mathrm{C}_{6} \mathrm{H}_{2} \mathrm{Me}_{3}$ $2,4,6$.

The NMR data for $[4]^{+}$indicate that the cation possesses time-averaged $C_{s}$ symmetry, but do not distinguish between the 'AuCl' unit adding syn or anti to the Tp* ligand (vide infra). The datum of most interest is the carbyne carbon resonance at $\delta_{\mathrm{C}}=$ 233.9 which is only shifted slightly to higher field from that for $[1 \mathrm{a}]^{+}\left(\delta_{\mathrm{C}}=246.9^{5 b}\right)$. In contrast to $[1 \mathrm{a}]^{+}$for which ${ }^{1} J_{\mathrm{CP}}$ is not resolved, this increases to $32 \mathrm{~Hz}$ in [4] $]^{+}$. This is contrary to simple hybridization arguments $\left(s p \rightarrow s p^{2}\right)$ but is a recurrent though less pronounced feature for the complexes to follow.

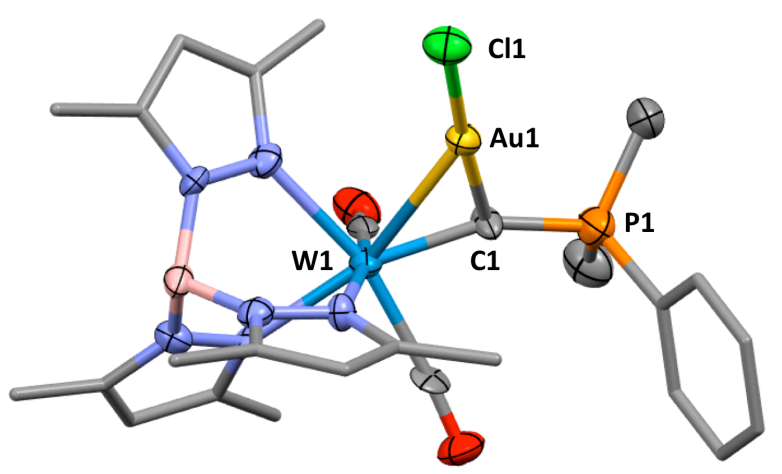

Figure 2. Molecular structure of [4] ${ }^{+}$in a crystal of [4] $\mathrm{PF}_{6}(50 \%$ displacement ellipsoids, pyrazolyl groups simplified and hydrogen atoms and counter-anion omitted for clarity). Selected distances $[\dot{A}]$ and angles [ ${ }^{\circ}$ ]: Au1-W1 2.7553(7), Au1-Cl1 2.276(4), Au1-C1 2.072(12), W1-C1 1.908(13), P1-C1 1.768(14), C3-W1-Au1 110.5(4), Cl1-Au1-W1 139.95(11), C1-Au1-W1 43.8(4), C1-Au1-Cl1 176.3(4), C1-W1-Au1 48.7(4).

The molecular structure of the cation [4] $]^{+}$is depicted in Figure 2 from which it is clear that the phosphoniocarbyne assumes a semi-bridging coordination mode, such that the W1C1-P1 angle $\left(152.8(7)^{\circ}\right)$ is considerably larger than found in the small number of symmetrical homobimetallic examples (128.0$\left.136.9^{\circ}\right) .{ }^{3 \mathrm{k}, 4}$ The $\mathrm{Cl} 1-\mathrm{Au} 1-\mathrm{C} 1$ angle of $176.3(4)^{\circ}$ is however essentially linear and the $\mathrm{AuCl}$ unit is shown to have added syn to the Tp* ligand, nestling within the cleft provided by two pyrazolyl groups. Bonding within the tungsta-auracyclopropene ring is discussed in more detail below.
A similar reaction ensues between [1a]PF 6 and $\left[\mathrm{CuCl}\left(\mathrm{SMe}_{2}\right)\right]$ with the distinction that a tetrametallic complex $\left[\mathrm{W}_{2} \mathrm{Cu}_{2}(\mu-\right.$ $\left.\left.\mathrm{CPMe}_{2} \mathrm{Ph}\right)_{2}(\mu-\mathrm{Cl})_{2}(\mathrm{CO})_{4}\left(\mathrm{Tp}^{*}\right)_{2}\right] \quad\left([5]\left[\mathrm{PF}_{6}\right]_{2}\right.$, Figure 3$)$ is formed bridged by a quadrilateral $\mathrm{Cu}_{2} \mathrm{Cl}_{2}$ unit as previously observed for the aminocarbyne complex $\left[\mathrm{W}_{2} \mathrm{Cu}_{2}(\mu \text {-CNMeEt })_{2}(\mu\right.$ $\left.\mathrm{Cl}_{2}(\mathrm{CO})_{4}(\mathrm{Cp})_{2}\right] \quad(\mathrm{Cp}=$ cyclopentadienyl $),{ }^{18}$ reflecting the propensity for increased coordination by copper(I) relative to $\operatorname{gold}(\mathrm{I})$. As for [4] the metal halide is appended syn to the Tp* ligand and geometric features within the two dimetallacyclopropene units once again indicate a lengthening of the WC bond upon coordination to copper with each copper positioned essentially orthogonal (W1-C1-Cu1 89.9(7) ${ }^{\circ}$, W1A$\left.\mathrm{C} 1 \mathrm{~A}-\mathrm{Cu} 1 \mathrm{~A} 89.1(5)^{\circ}\right)$ to the respective $\mathrm{WC}$ bonds. The $\mathrm{W}-\mathrm{Cu}$ (2.685(2), 2.669(2) $\AA$ ) and WC bond lengths (1.892(16), $1.874(12) \AA$ ) are not significantly different to those found for the neutral and less sterically encumbered aminocarbyne complex $\left[\mathrm{W}_{2} \mathrm{Cu}_{2}(\mu-\mathrm{CNMeEt})_{2}(\mu-\mathrm{Cl})_{2}(\mathrm{CO})_{4}(\mathrm{Cp})_{2}\right](2.610(1)$ and 1.89(1) $\AA$, respectively), whilst the $\mathrm{Cu}-\mathrm{C}$ distances (1.909(15), $1.932(15) \AA)$ are marginally contracted $c f$. that found for the amino derivative (2.01(1) $\AA$ ). ${ }^{18}$

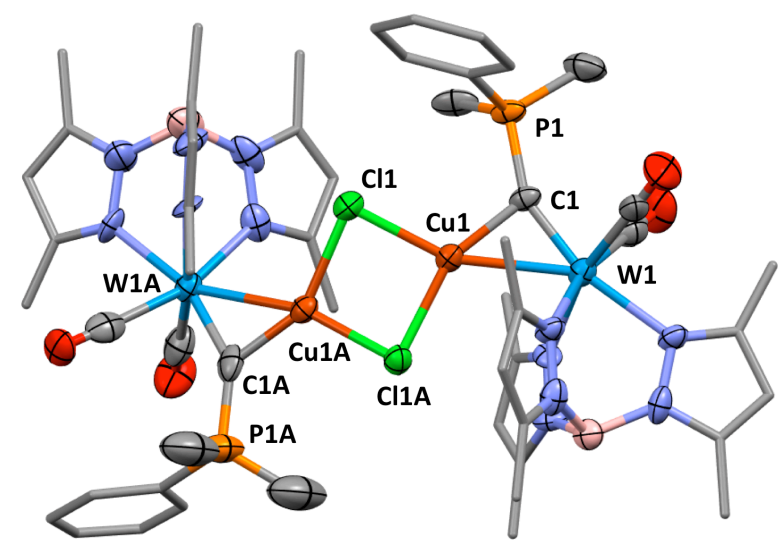

Figure 3. Molecular structure of [5] $]^{2+}$ in a crystal of [5] $\left(\mathrm{PF}_{6}\right)_{2}(50 \%$ displacement ellipsoids, pyrazolyl and phenyl and COD groups simplified, hydrogen atoms and counter-anion omitted for clarity). Selected bond lengths ( $(\AA)$ and angles $\left({ }^{\circ}\right)$ : W1-Cu1 2.685(2), W1ACu1A 2.669(2), W1-C1 1.892(16), W1A-C1A 1.874(12), Cu1-Cl1 2.292(3), Cu1A-Cl1 2.302(4), Cu1A-Cl1A 2.275(4), Cu1-C1 1.909(15) Cu1A-C1A 1.932(13), P1-C1 1.777(17), P1A-C1A 1.790(12), C1A-W1A-Cu1A 46.4(4), C1-W1-Cu1 45.3(4), W1-C1-Cu1 89.9(7), W1A-C1A-Cu1A 89.1(5), P1-C1-W1 146.1(8), W1A-C1A-Cu1A 89.1(5), P1A-C1AW1A 153.1(8).

A plethora of tungsten-platinum bridging carbyne complexes is known from the studies of Stone, ${ }^{19}$ who employed the reagent $\left[\mathrm{Pt}(\mathrm{COD})_{2}\right](\mathrm{COD}=1,5$-cyclo-octadiene $)$ to great effect in the construction of polymetallic 'bow-ties', ${ }^{19 b}$ chains ${ }^{19 c}$ and rings. ${ }^{19 d}$ These all involve simple aryl or alkyl carbyne substituents although recently the parent bis(methylidyne) bow-tie $\left[\mathrm{W}_{2} \mathrm{Pt}(\mu-\mathrm{CH})(\mathrm{CO})_{4}\left(\mathrm{Tp}^{*}\right)_{2}\right]$ was isolated, ${ }^{20}$ in addition to complexes in which platinum is coordinated by $\mathrm{W} \equiv \mathrm{C}-\mathrm{C} \equiv \mathrm{W}$ and $\mathrm{W} \equiv \mathrm{CC} \equiv \mathrm{CC} \equiv \mathrm{CC} \equiv \mathrm{W}$ sub-units. ${ }^{21}$ The reaction of $[1] \mathrm{PF}_{6}$ with $\left[\mathrm{Pt}(\mathrm{nbe})_{3}\right]$ (nbe $=$ norbornene) in the presence of COD does not proceed to the formation of a bow-tie trimetallic complex, but rather stops at the 1:1 adduct stage, presumably on steric grounds, with the formation of the salt $[\mathrm{WPt}(\mu-$ $\left.\left.\mathrm{CPMe}_{2} \mathrm{Ph}\right)(\mathrm{CO})_{2}(\mathrm{COD})\left(\mathrm{Tp}^{*}\right)\right]\left[\mathrm{PF}_{6}\right]\left([6] \mathrm{PF}_{6}\right.$, Figure 4). 


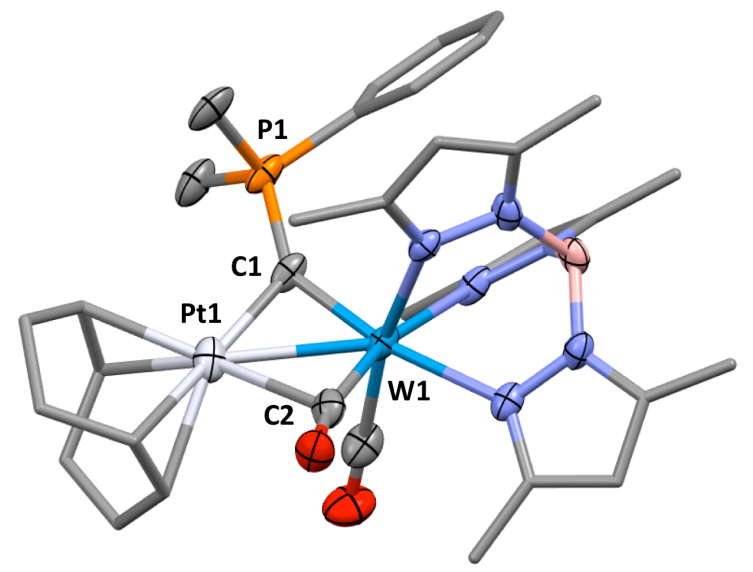

Figure 4. Molecular structure of [6] ${ }^{+}$in a crystal of $[6]\left(\mathrm{PF}_{6}\right)(50 \%$ displacement ellipsoids, pyrazolyl, phenyl and COD groups simplified, hydrogen atoms and counter-anion omitted for clarity, one of two independent molecules shown, See also Table 2). Selected bond lengths (Å) and angles ( ${ }^{\circ}$ ): W1-Pt1 2.7284(7), W1-C1 1.976(10), Pt1-C1 1.998(12), Pt1‥C2 2.460(12), P1-C1 1.750(11), C1-W1-Pt1 47.0(4), C1-Pt1-W1 46.3(3), W1-C1-Pt1 86.7(4), P1-C1-W1 143.5(7), P1-C1-Pt1 128.8(6).

Although the carbonyl associated infrared data are very similar to those for $[4]^{+}$, the molecular structure (Figure 4) indicates that in the solid state one carbonyl ligand adopts a

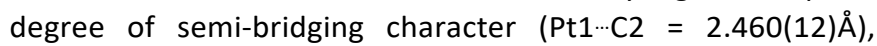
although this is not apparently retained in solution, with only a single carbonyl environment being observed in the ${ }^{13} \mathrm{C}\left\{{ }^{1} \mathrm{H}\right\} \mathrm{NMR}$ spectrum consistent with time-averaged $C_{s}$ local symmetry. The carbyne resonance (272.8 ppm) is shifted considerably downfield relative to both [4] ${ }^{+}$and the precursor [1a $]^{+}$. In the ${ }^{31}{ }^{1}\left\{{ }^{1} \mathrm{H}\right\}$ NMR spectrum, the phosphonium resonance is straddled by satellites due to tungsten-183 $\left({ }^{2} J_{\mathrm{WP}}=71.3 \mathrm{~Hz}\right)$ and platinum-195 $\left({ }^{2} J_{\mathrm{PtP}}=193.4 \mathrm{~Hz}\right)$ isotopomers. The most directly comparable structural data for comparison with those for [6] $]^{+}$ are the 'carbon-wire' adducts $\left[\mathrm{W}_{2} \mathrm{Pt}\left(\mu-\mathrm{C}_{2}\right)(\mathrm{COD})(\mathrm{CO})_{4}\left(\mathrm{Tp}^{*}\right)_{2}\right]^{21 \mathrm{a}}$ and $\left[\mathrm{W}_{2} \mathrm{Pt}_{\mathrm{x}}\left(\mu-\mathrm{C}_{6}\right)(\mathrm{COD})_{x}(\mathrm{CO})_{4}\left(\mathrm{Tp}^{*}\right)_{2}\right]\left(\mathrm{x}=1,2,{ }^{21 \mathrm{~b}}\right.$ Chart 2$)$. These each feature a tungstaplatina-cyclopropene moiety that includes a semi-bridging carbonyl ligand, as is often observed for heterobimetallic metal-metal bonded species with disparate ('early-late') metal centres. ${ }^{22}$ Geometrical parameters for the dimetallacyclopropene (Table 2) are essentially similar within precision limits (6 e.s.d.) to those described for other examples ${ }^{20,21}$ such that the bridging carbyne can be described as demonstrating semi-bridging character with a large $\mathrm{W}-\mathrm{C}-\mathrm{P}$ angle $\left(143.5^{\circ}\right)$. Consistent with C-P $p \pi-p \pi$ overlap not being significant coordination of the 'Pt(COD)' unit does not significantly alter the C1-P1 bond length $(1.750(11) \AA)$ from that found for $[\mathbf{1 a}]^{+}(1.79(1) \AA)$ however the $\mathrm{W}-\mathrm{C}$ bond length increases significantly (1.998(12), 1.976(10) $\AA$ ) from that of the terminal carbyne ligand in $[1 \mathbf{a}]^{+}(1.821(9) \AA)$. We will return to the nature of the bonding within the dimetallacyclopropene following the discussion of further examples (vide infra).

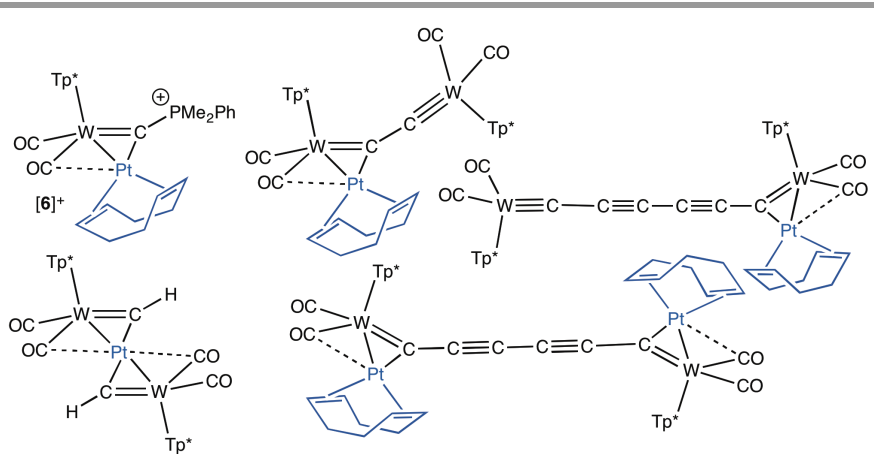

Chart 2. Tp*-ligated Tungstaplatinacyclopropenes. ${ }^{20,21}$

Table 2. Geometric features of $T p^{*}$-ligands tungstametallacyclopropenes. [W] $=$ $\left.\mathrm{W}(\mathrm{CO})_{2}(\mathrm{Tp})^{*}\right),[\mathrm{Pt}]=\mathrm{Pt}(\mathrm{COD}), \mathrm{M}=\mathrm{Pt}, \mathrm{Au}, \mathrm{Cu}$.

\begin{tabular}{llllll} 
Complex & WC & MC & WM & WCM & WCR \\
& {$[\AA ̊]$} & {$[\AA ̊]$} & {$[\AA ̊]$} & {$\left[^{\circ}\right]$} & {$\left[^{\circ}\right]$} \\
\hline
\end{tabular}

$\begin{array}{llllll}{[\mathbf{4}]^{+}} & 1.908(13) & 2.072(12) & 2.7553(7) & 87.5(5) & 152.8(7) \\ {[\mathbf{5}]^{2+}} & 1.892(16) & 1.909(15) & 2.685(2) & 89.9(7) & 146.1(8) \\ & 1.874(2) & 1.932(15) & 2.669(2) & 89.1(5) & 153.1(8) \\ {[6]^{+a}} & 1.998(12) & 1.981(10) & 2.7375(6) & 87.8(4) & 143.5(6) \\ & 1.976(10) & 1.998(12) & 2.7284(7) & 86.7(4) & 143.5(7) \\ {[\mathbf{7}]^{+}} & 1.970(6) & 1.965(5) & 2.7592(3) & 89.0(2) & 138.1(3) \\ {[8]^{+}} & 1.968(5) & 1.982(5) & 2.7528(3) & 88.4(2) & 139.6(3) \\ {[\mathbf{W}]_{2}(\mu-\mathrm{CH})_{2} \mathrm{Pt}^{20}} & 1.929(8) & 2.046(7) & 2.7277(4) & 86.6(3) & 136.7^{b} \\ & 1.910(8) & 2.001(7) & 2.7518(5) & 89.4(3) & 135.3^{b} \\ {[\mathrm{~W}]_{2}\left(\mu-\mathrm{C}_{2}\right)^{21 \mathrm{a}, \mathrm{c}}} & 1.89(2) & 2.11(1) & 2.740(1) & 86.3(4) & 157.6(9) \\ & 1.982(5) & 2.031(5) & 2.6965(3) & 84.4(2) & 152.2(4) \\ {[\mathrm{W}]_{2}\left(\mu-\mathrm{C}_{6}\right)[\mathrm{Pt}]^{21 \mathrm{~b}}} & 1.972(5) & 2.014(6) & 2.7351(4) & 86.6(2) & 146.2(5) \\ {[\mathrm{W}]_{2}\left(\mu-\mathrm{C}_{6}\right)[\mathrm{Pt}]_{2}{ }^{21 \mathrm{~b}}} & 1.976(7) & 2.021(7) & 2.7148(4) & 85.6(3) & 150.7(5) \\ & 1.951(7) & 2.018(7) & 2.7260(4) & 86.8(3) & 148.9(6) \\ {[10]^{+d}} & 1.937 & 1.980 & 2.789 & 90.8 & 139.1 \\ {[\mathbf{1 1}]^{+d}} & 1.885 & 2.065 & 2.866 & 92.9 & 151.5\end{array}$

${ }^{a}$ Two crystallographically unique molecules. ${ }^{b}$ Hydrogen substituent located but not refined. cStructural model involves disorder, more precise data for nbd derivative given in parentheses. " ${ }^{d}$ Calculated geometry (Gas phase, $\omega B$ B97X-D/6$31 \mathrm{G} * /$ LANL2D $\zeta)$.

The COD ligand in [6] $]^{+}$is potentially labile and could be replaced by slender isonitrile ligands without disrupting the central dimetallacyclopropene core. Thus treating [6]PF 6 with CNR results in the formation of the salts [WPt $(\mu-$ $\left.\left.\mathrm{CPMe}_{2} \mathrm{Ph}\right)(\mathrm{CO})_{2}(\mathrm{CNR})_{2}\left(\mathrm{Tp}^{*}\right)\right] \mathrm{PF}_{6}\left(\mathrm{R}={ }^{t} \mathrm{Bu}[7] \mathrm{PF}_{6}\right.$, Mes $=\mathrm{C}_{6} \mathrm{H}_{2} \mathrm{Me}_{3}-$ $\left.2,4,6[8] \mathrm{PF}_{6}\right)$, both of which were structurally characterized (Figures 5 and 6). 


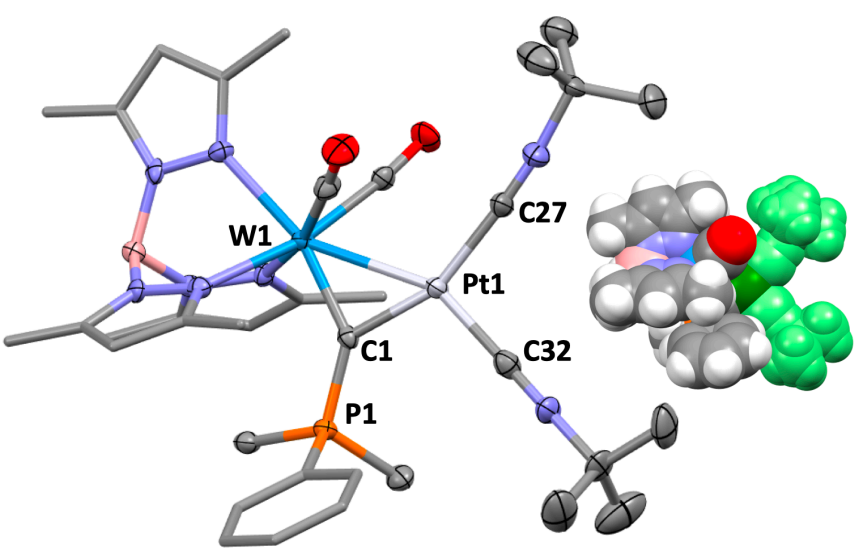

Figure 5. Molecular structure of (a) [7] $]^{+}$in a crystal of $[7] \mathrm{PF}_{6} . \mathrm{CHCl}_{3}(50 \%$ displacement ellipsoids, pyrazolyl groups simplified, hydrogen atoms and counter-anion omitted for clarity). Selected distances $[\dot{A}]$ and angles [ $\left.{ }^{\circ}\right]$ : (a) W1-Pt1 2.7592(3), W1-C1 1.970(6), Pt1-C1 1.965(5), Pt1-C27 1.990(6), Pt1-C32 1.952(7), P1-C1 1.749(6), C1-W1-Pt1 45.42(16), C1-Pt1-C27 157.8(2), C27-Pt1-W1 112.26(17), C32-Pt1-W1 152.29(18), C32Pt1-C1 106.7(2), C32-Pt1-C27 95.4(2). Inset = space-filling representation with docking of the ' $\mathrm{Pt}\left(\mathrm{CN}^{t} \mathrm{Bu}\right)_{2}$ ' unit shown in green.

In both cases, the ' $\mathrm{Pt}(\mathrm{CNR})_{2}$ ' unit adopts a position anti to the Tp* ligand, as with [6]+ but in contrast to $[4]^{+}$and $[5]^{2+}$ where the metals and $\mathrm{Tp}^{*}$ ligands are mutually syn disposed. Accordingly, one methyl of the $\mathrm{PMe}_{2} \mathrm{Ph}$ unit is cradled by two pyrazolyl groups, although free rotation about the $\mathrm{C}-\mathrm{PMe} \mathrm{P}_{2} \mathrm{Ph}$ bond occurs in solution on the ${ }^{1} \mathrm{H}$ and ${ }^{13} \mathrm{C}$ NMR timescales.

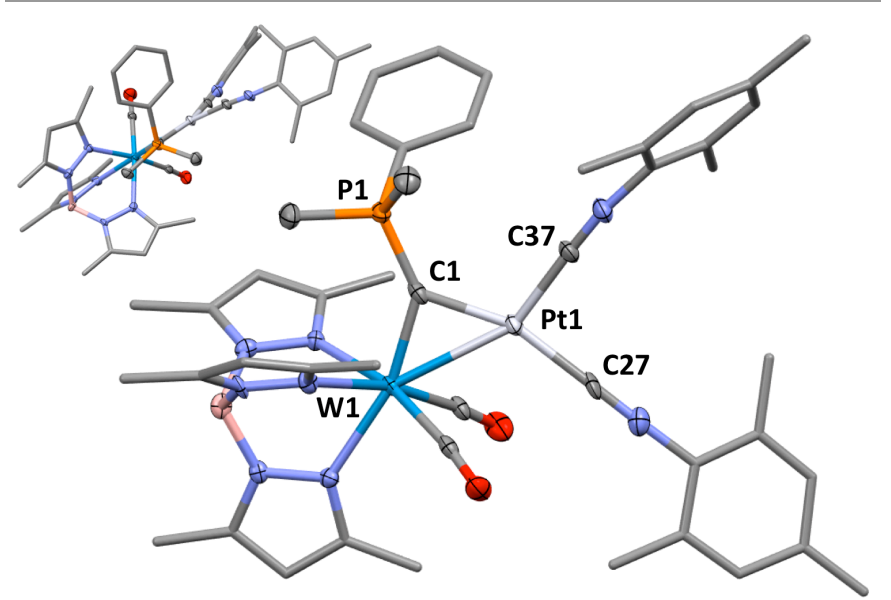

Figure 6. Molecular structure of (a) [8] $]^{+}$in a crystal of $[8] \mathrm{PF}_{6} \cdot \mathrm{CHCl}_{3}(50 \%$ displacement ellipsoids, pyrazolyl groups simplified, hydrogen atoms and counter-anion omitted for clarity). Selected distances $[\dot{A}]$ and angles [ $\left.{ }^{\circ}\right]$ : Pt1 W1 2.7528(3), Pt1-C1 1.982(5), Pt1C37 1.930(5), Pt1-C27 1.963(6), W1-C1 1.968(5), P1-C1 1.746(5), C1-Pt1-W1 45.60(14), C37-Pt1-W1 152.88(16), C37-Pt1-C1 107.9(2), C37-Pt1-C27 93.6(2), C27-Pt1-W1 113.25(15), C27-Pt1-C1 158.3(2), W1-C1-Pt1 88.4(2), P1-C1-Pt1 132.0(3), P1-C1-W1 139.6(3). Inset = view along the platinum coordination plane.

With the two isonitriles adopting essentially orthogonal coordination sites $\left(\mathrm{C}-\mathrm{Pt}-\mathrm{C}=95.4(2)^{\circ}[7]^{+} ; 93.6(2)^{\circ}[8]^{+}\right)$, the coordination at platinum might be described as distorted square planar $d^{8}-\mathrm{Pt} \quad \mathrm{MX}_{2} \mathrm{~L}_{2}$ (dimetallacyclopropene) or alternatively trigonal planar $d^{10}-\mathrm{Pt} \mathrm{ML}_{3}$ (complexed carbyne, Chart 3). Accordingly, the bonding within the dimetallacyclopropenes was explored with recourse to DFT

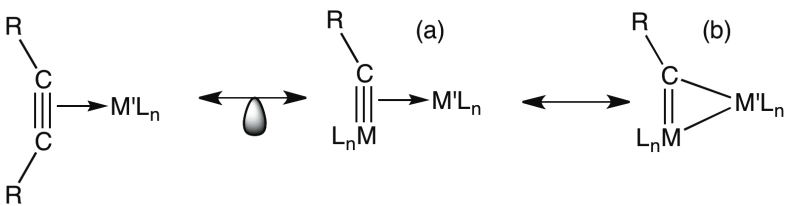

Chart 3. Isolobal relationship between coordination of an alkyne or carbyne to a metal. Dewar-Chatt-Duncanson perspective of (a) Complexed carbyne and (b) Dimetallacyclopropene.

( $\omega$ B97X-D/6-31G*/LANL2D $\zeta$, gas phase) analysis of the simpler analogue $\left[\mathrm{WPt}\left(\mu-\mathrm{CPMe}_{3}\right)(\mathrm{CO})_{2}(\mathrm{CNMe})_{2}(\mathrm{Tp})\right]^{+} \quad\left([10]^{+}: \mathrm{Tp}=\right.$ hydrotris(pyrazolyl)borate). The tungstaplatinacyclopropenes $\left.\left[\mathrm{WPt}(\mu-\mathrm{CR})(\mathrm{CO})_{2}\left\{\mathrm{P}(\mathrm{OMe})_{3}\right\}_{2}\right](\mathrm{Tp})\right] \quad\left(\mathrm{R}=\mathrm{Me}, \mathrm{C}_{6} \mathrm{H}_{4} \mathrm{Me}-4\right)$ and $\left[\mathrm{W}_{2} \mathrm{Pt}(\mu-\mathrm{CR})_{2}(\mathrm{CO})_{4}(\mathrm{Tp})_{2}\right]$ ligated by the more sterically compact $\mathrm{Tp}$ ligand have been described previously ${ }^{23}$ and $\left[\mathrm{W}_{2} \mathrm{Pt}(\mu-\right.$ $\left.\mathrm{CMe})_{2}(\mathrm{CO})_{4}(\mathrm{Tp})_{2}\right]$ has been structurally authenticated, suggesting the Tp/Tp* approximation is reasonable. The optimised geometry for $[\mathbf{1 0}]^{+}$is sufficiently close to those experimentally determined for $[\mathbf{7}]^{+}$and $[8]^{+}$and is presented in Figure 7 which also depicts the molecular orbitals of interest. For the complex $\left[\mathrm{W}_{2} \mathrm{Pt}(\mu-\mathrm{CMe})_{2}(\mathrm{CO})_{4}(\mathrm{Tp})_{2}\right]$, the $\mathrm{W}-\mathrm{Pt}$ bond lengths (2.713(1), 2.720(1) $\AA$ ) are somewhat shorter than those for the $\mathrm{Tp}^{*}$ derivatives in Table 2 however Pt-C (2.034(8), $2.045(9) \AA)$ are longer with more pronounced semi-bridging character (W-C-C: $\left.153.9(7), 155.9(7)^{\circ}\right)$, i.e., some geometric response to the disparate steric profiles of $\mathrm{Tp}$ and $\mathrm{Tp} *$ ligands is to be expected. In electronic terms, the Tp* ligand is marginally more electron releasing than the Tp ligand. ${ }^{24,25}$ In the context of isolobal considerations that map the coordination of $M \equiv C$ and $\mathrm{C} \equiv \mathrm{C}$ bonds to extraneous metals, ${ }^{11,25}$ from a Dewar-ChattDuncanson perspective, the molecular orbitals presented in Figure 1 for the neopentylidyne complex WC and the phosphoniocarbyne complex WP would appear to suggest that both are comparable $\pi$-acceptors but that the latter is a significantly weaker $\sigma$-donor. In valence bond terms this would be described as greater contribution from the dimetallacycloropene canonical form (Chart 3b) than the description as a complexed carbyne (Chart 3a).

The optimised geometry and molecular orbitals of interest are depicted in Figure 7. As in the experimentally determined structures for [7]+ and [8]+, the WCP unit is essentially co-planar with the $\mathrm{Pt}(\mathrm{CNMe})_{2}$ unit and minor variations may be attributed to the different steric profiles of the $\mathrm{Tp} / \mathrm{Tp}^{*}, \mathrm{PMe}_{3} / \mathrm{PMe}_{2} \mathrm{Ph}$ and $\mathrm{CNMe} / \mathrm{CN}^{t} \mathrm{Bu}$ replacements. The $\mathrm{W}-\mathrm{C}, \mathrm{Pt}-\mathrm{C}$ and $\mathrm{W}-\mathrm{Pt}$ Wiberg bond orders calculated within the Löwdin basis ${ }^{26}$ are 1.690 , 1.066 and 0.811 , respectively, consistent with the dimetallacyclopropene description, while that for the C-P bond (1.058) is close to unity, apparently discounting any significant $\mathrm{p} \pi-\mathrm{p} \pi$ overlap. The bridging carbyne carbon carries a negative natural charge $(-1.286)$ whilst the tungsten $(+0.916)$, platinum $(+1.130)$ and phosphorus $(+1.663)$ carry positive charges. 


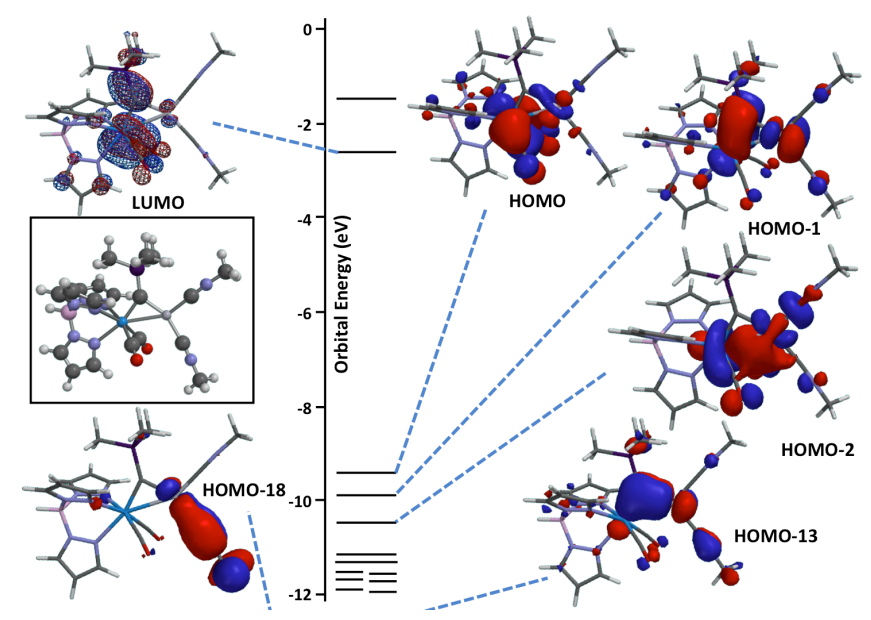

Figure 7. Optimised geometry and molecular orbitals of interest for the cationic complex $\left.\left[\mathrm{WPt}(\mu-\mathrm{CPMe})_{3}\right)(\mathrm{CO})_{2}(\mathrm{CNMe})_{2}(\mathrm{Tp})\right]^{+}[\mathbf{1 0}]^{+}\left(\omega \mathrm{B} 97 \mathrm{X}-\mathrm{D} / 6-31 \mathrm{G}^{*} / \mathrm{LANL} 2 \mathrm{D} \zeta\right.$, gas phase).

The HOMO of $[\mathbf{1 0}]^{+}$remains the orbital primarily associated with tungsten carbonyl binding while the HOMO-1 corresponds to the $\mathrm{W}-\mathrm{C} \pi$-bond orthogonal to the WPtC ring but includes a sizeable contribution from a platinum $\pi$-orbital with Pt-C and Pt$W$ antibonding character. This is reminiscent of the destabilising nature of '4-electron alkyne' coordination to metals with high d-occupancies. ${ }^{27}$ For '4-electron carbyne' coordination to midtransition metals (e.g., $\mathrm{d}^{8}{ }_{-}{ }^{\prime} \mathrm{Fe}(\mathrm{CO})_{3}{ }^{\prime}$ and $\mathrm{d}^{6}{ }_{-}{ }^{\prime} \mathrm{Mo}(\mathrm{CO})_{2}$ ' units) this is a stabilising interaction. ${ }^{15,28}$ The HOMO-2 corresponds primarily to $\mathrm{W}$-Pt $\sigma$-bonding, HOMO-12 is both $\mathrm{W}-\mathrm{C}$ and $\mathrm{Pt}-\mathrm{C}$ $\sigma$-bonding, while HOMO-13 is completely WCPt $\pi$-bonding and HOMO-18/19 are responsible for Pt-isonitrile retrodonation. The LUMO is of note in being substantially derived from $\mathrm{C} \pi-\mathrm{P} \pi$ overlap but with a $\pi$-antibonding interaction between carbon and tungsten such that nucleophilic attack at the bridging carbyne carbon is both favoured and likely to reduce the $\mathrm{W}-\mathrm{C}$ multiple bonding.

The hypothetical complex [WAu( $\left.\left.\mu-\mathrm{CPMe}_{3}\right) \mathrm{Cl}(\mathrm{CO})_{2}(\mathrm{Tp})\right]^{+}$ $\left([\mathbf{1 1}]^{+}\right)$was also considered as a pruned model for [4]+ (Figure 8). While the two canonical descriptions in Chart 3 are both useful in describing the platinum adducts, in the case of gold, the dimetallacyclopropene formalism invokes trivalent gold(III), which is less plausible. The HOMO and LUMO are similar in topology and composition as those for $[\mathbf{1 0}]^{+}$but are separated by a slightly larger energy gap (ca $7.3 \mathrm{eV} c f .6 .8 \mathrm{eV}$ for [10]+). The HOMO-1 and HOMO-4 are both WC p-bonding with the former including $\mathrm{Au}-\mathrm{C}$ and $\mathrm{Au}-\mathrm{W} \pi$-antibonding components, but with substantial $\mathrm{Au}-\mathrm{Cl} \pi$-antibonding character. The Löwdin bond orders for the W-C (1.896), Au-C (0.803) and W-Au (0.641) bonds point towards weaker coordination of the $\mathrm{AuCl}$ unit $c f . \mathrm{Pt}(\mathrm{CNMe})_{2}$ with natural charges on tungsten (1.069) and the carbyne carbon $(-1.245)$ indicating comparable transfer of electron density from tungsten to gold $(+1.044)$ as for platinum in $[10]^{+}$. This is contrary to expectations based on calculated and experimental $v_{c o}$ frequencies (calcd 2042, 1983 ([4]+: 2037, 1961] for [11 $]^{+}$cf. 1982, $1928\left([\mathbf{8}]^{+}: 1941,1853\right) \mathrm{cm}^{-1}$ for $\left.[\mathbf{1 0}]^{+}\right)$ which may be explained by the synergic nature of the WCO bonding.

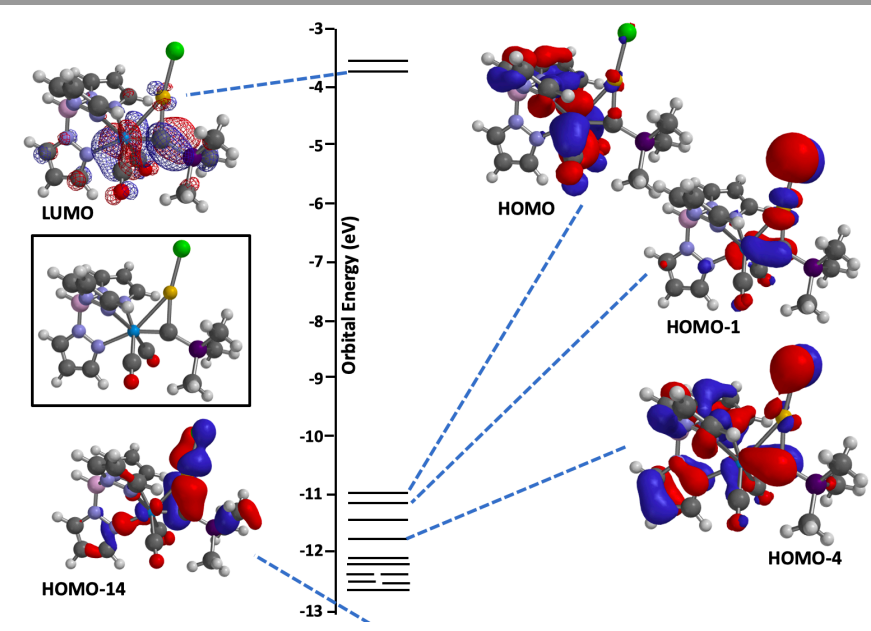

Figure 8. Optimised geometry and molecular orbitals of interest for the cationic complex $\left[\mathrm{WAu}\left(\mu-\mathrm{CPMe}_{3}\right) \mathrm{Cl}(\mathrm{CO})_{2}(\mathrm{Tp})\right]^{+}[11]^{+}\left(\omega \mathrm{B} 97 \mathrm{X}-\mathrm{D} / 6-31 \mathrm{G}^{*} / \mathrm{LANL} 2 \mathrm{D} \zeta\right.$, gas phase).

\section{Conclusions}

In conclusion, phosphoniocarbynes are shown to serve as building blocks for the strategic bridge-assisted synthesis of heterobimetallic assemblies in much the same way as more conventional carbynes. The positive charge on the phosphonium substituent has a rather modest impact on the $\pi$ acidity of the WC unit towards an extraneous metal but decreases its basicity, resulting in less effective transfer of electron density to the metal. Nevertheless, the resulting dimetallacyclopropene core of, e.g., $\quad[\mathrm{WPt}(\mu-$ $\left.\left.\mathrm{CPMe}_{2} \mathrm{Ph}\right)(\mathrm{COD})(\mathrm{CO})_{2}\left(\mathrm{Tp}^{*}\right)\right]^{+}[6]^{+}$is robust and endures during co-ligand substitutions (COD replacement).

\section{Experimental}

\section{General}

Experimental work was performed using standard Schlenk techniques with dried and pre-purified nitrogen or in an inert atmosphere glove-box charged with an argon atmosphere unless specified otherwise. Reactions employed dried and degassed solvents distilled over sodium and benzophenone (ethers, arenes and paraffins) or calcium hydride $\left(\mathrm{CH}_{2} \mathrm{Cl}_{2}\right)$. The compounds $\quad\left[\mathrm{W}\left(\equiv \mathrm{CPMe}_{2} \mathrm{Ph}\right)(\mathrm{CO})_{2}\left(\mathrm{Tp}^{*}\right)\right] \mathrm{PF}_{6} \quad[1 \mathrm{a}] \mathrm{PF}_{6} \quad$ was prepared via a minor modification of the method reported by Templeton (vide infra). ${ }^{5}$ The compounds $\left[\mathrm{Pt}(\mathrm{nbe})_{3}\right]^{29}$ $[\mathrm{AuCl}(\mathrm{THT})]^{30}$ and $\left[\mathrm{CuCl}\left(\mathrm{SMe}_{2}\right)\right]^{31}$ were prepared according to published procedures. All other reagents were used as received from commercial suppliers.

NMR spectra were obtained on a Bruker Avance $400\left({ }^{1} \mathrm{H}\right.$ at 400.1, ${ }^{13} \mathrm{C}\left\{{ }^{1} \mathrm{H}\right\}$ at $100.6,{ }^{19} \mathrm{~F}\left\{{ }^{1} \mathrm{H}\right\}$ at $376.5,{ }^{11} \mathrm{P}\left\{{ }^{1} \mathrm{H}\right\}$ at 162.0 , ${ }^{195} \mathrm{Pt}\left\{{ }^{1} \mathrm{H}\right\}$ at $\left.85.7 \mathrm{MHz}\right)$, a Bruker Avance $600\left({ }^{1} \mathrm{H}\right.$ at $600.0,{ }^{13} \mathrm{C}\left\{{ }^{1} \mathrm{H}\right\}$ at $150.9 \mathrm{MHz})$ or a Bruker Avance $700\left({ }^{1} \mathrm{H}\right.$ at $700.0,{ }^{13} \mathrm{C}\left\{{ }^{1} \mathrm{H}\right\}$ at $176.1,{ }^{31} \mathrm{P}\{1 \mathrm{H}\}$ at $283.4 \mathrm{MHz}$ ) spectrometers at the temperatures indicated. Chemical shifts $(\delta)$ are reported in ppm with coupling constants given in $\mathrm{Hz}$ and are referenced to the solvent resonance or external references $\left\{\mathrm{CFCl}_{3}\right.$ for ${ }^{19} \mathrm{~F}\left\{{ }^{1} \mathrm{H}\right\}, 85 \% \mathrm{H}_{3} \mathrm{PO}_{4}$ in $\mathrm{H}_{2} \mathrm{O}$ for ${ }^{31} \mathrm{P}\left\{{ }^{1} \mathrm{H}\right\}, 1.2 \mathrm{M} \mathrm{Na}_{2} \mathrm{PtCl}_{6}$ for $\left.{ }^{195} \mathrm{Pt}\right\}$. The multiplicities of 
NMR resonances are denoted by the abbreviations s (singlet), $d$ (doublet), $\mathrm{t}$ (triplet), $\mathrm{m}$ (multiplet), br (broad) and combinations thereof for more highly coupled systems. Where applicable, the stated multiplicity refers to that of the primary resonance exclusive of ${ }^{183} \mathrm{~W}$ or ${ }^{195} \mathrm{Pt}$ satellites. In select cases, distinct peaks were observed in the ${ }^{1} \mathrm{H}$ and ${ }^{13} \mathrm{C}\left\{{ }^{1} \mathrm{H}\right\}$ NMR spectra, but to the level of accuracy that is reportable (i.e., 2 decimal places for ${ }^{1} \mathrm{H}$ NMR, 1 decimal place for ${ }^{13} \mathrm{C}\left\{{ }^{1} \mathrm{H}\right\}$ NMR) they are reported as having the same chemical shift.

Spectra provided in the electronic supporting information generally correspond to samples obtained directly from chromatography and may contain residual solvent as recrystallised samples often display reduced solubility. The $\mathrm{BH}$ protons give rise to very broad signals around $4-5 \mathrm{ppm}$ in the ${ }^{1} \mathrm{H}$ NMR spectra due to coupling to the quadrupolar boron nuclei. These are not listed in the experimental NMR data in all cases as their chemical shifts and associated integrals are not determined accurately. The $\mathrm{BH}$ unit, being remote from the metal centre of interest is not particularly responsive to variations and accordingly ${ }^{11} \mathrm{~B}\left\{{ }^{1} \mathrm{H}\right\}$ NMR spectra were not recorded.

Infrared spectra were obtained using a Shimadzu FTIR-8400 spectrometer (liquid) or Perkin Elmer FTIR Spectrum 2 (Solid State ATR, diamond anvil). Signals are denoted according to their absorption strength such as very sharp (vs), strong (s), medium ( $m$ ), weak ( $w$ ) or broad (br). Elemental microanalytical data were provided by the London Metropolitan University. Solvates evident from data were confirmed where possible by NMR spectroscopy. High-resolution electrospray ionisation mass spectrometry (ESI-MS) was performed by the ANU Research School of Chemistry mass spectrometry service with acetonitrile or dichloromethane as the matrix.

Data for X-ray crystallography were collected with Agilent Xcalibur or SuperNova CCD diffractometers using Mo-K $\alpha$ radiation $(\lambda=0.71073 \dot{A})$ or $\mathrm{Cu}-\mathrm{K} \alpha$ radiation $(\lambda=1.54184 \dot{A})$ employing the CrysAlis PRO software. ${ }^{32}$ The structures were solved by direct or Patterson methods and refined by full-matrix least-squares on $F^{2}$ using the SHELXS or SHELXT and SHELXL programs. ${ }^{33}$ Hydrogen atoms were located geometrically and refined using a riding model. Diagrams were produced using the CCDC visualisation program Mercury. ${ }^{34}$

Computational studies were performed by using the SPARTAN18 suite of programs. ${ }^{35}$ Geometry optimisation (gas phase) was performed at the DFT level of theory using the $\omega B 97 X-D$ functional of Head-Gordon ${ }^{36}$ for WC, WSi, WN, WP and $[\mathbf{1 0}]^{+}$and $[\mathbf{1 1}]^{+}$. The Los Alamos effective core potential type basis set (LANL2D $\zeta$ ) of Hay and $\mathrm{Wadt}^{37}$ was used for Pt and W while Pople 6-31G* basis sets ${ }^{38}$ were used for all other atoms. Frequency calculations were performed to confirm that the optimized structures were minima and also to identify vibrational modes of interest ( $v_{w c}$ ). Cartesian atomic coordinates are provided in the electronic supporting information.

Synthesis of $\left[\mathrm{W}\left(\equiv \mathrm{CPPhMe}_{2}\right)(\mathrm{CO})_{2}\left(\mathrm{Tp}^{*}\right)\right]\left[\mathrm{PF}_{6}\right] \quad[1 \mathrm{a}] \mathrm{PF}$. A modified version of Templeton's synthesis was adopted. ${ }^{5}$ The changes include, using $\left[\mathrm{W}(\equiv \mathrm{CBr})(\mathrm{CO})_{2}\left(\mathrm{Tp}^{*}\right)\right]$ instead of $\left[\mathrm{W}(\equiv \mathrm{CCl})(\mathrm{CO})_{2}\left(\mathrm{Tp}^{*}\right)\right]$, replacing $\mathrm{KPF}_{6}$ with $\mathrm{NaPF}_{6}$ and using acetonitrile in place of dichloromethane as solvent. Following the same work-up procedure, $\left[\mathrm{W}(\equiv \mathrm{CPPhMe})(\mathrm{CO})_{2}\left(\mathrm{Tp}^{*}\right)\right]\left[\mathrm{PF}_{6}\right]$ [1a]PF 6 was obtained in essentially quantitative yield and the spectroscopic features match those reported previously. ${ }^{5}$ Previous IR data were acquired from THF solution, and NMR data were measured in $\mathrm{CD}_{2} \mathrm{Cl}_{2} .{ }^{5} \mathrm{IR}\left(\mathrm{CH}_{2} \mathrm{Cl}_{2}, \mathrm{~cm}^{-1}\right): 2022 \mathrm{~s}$, $1935 \mathrm{~s}$ $v_{\text {CO. }}{ }^{1} \mathrm{H}$ NMR (7Fse00 MHz, CDCl, $298 \mathrm{~K}$ ): $\delta_{\mathrm{H}}=2.14$ (s.br, $6 \mathrm{H}$, $\mathrm{PCH}_{3}, \mathrm{HSQC}$ with $\left.\delta_{\mathrm{C}}=11.0\right), 2.22,2.23,2.24(\mathrm{~s} \times 3,3 \mathrm{H} \times 3$, $\left.\mathrm{pzCH}_{3}\right), 2.31\left(\mathrm{~s}, 9 \mathrm{H}, \mathrm{pzCH}_{3}\right), 5.83(\mathrm{~s}, 1 \mathrm{H}, \mathrm{pzCH}), 5.92(\mathrm{~s}, 2 \mathrm{H}$, $\mathrm{pzCH}), 7.57\left[\mathrm{td},{ }^{3} \mathrm{~J}_{\mathrm{HH}}=7.7,3.3,2 \mathrm{H}, \mathrm{H}^{2}, 6\left(\mathrm{C}_{6} \mathrm{H}_{5}\right)\right], 7.66\left[\mathrm{t},{ }^{3} J_{\mathrm{HH}}=7.4\right.$, $\left.1 \mathrm{H}, \mathrm{H}^{4}\left(\mathrm{C}_{6} \mathrm{H}_{5}\right)\right], 7.78\left[\mathrm{dd}, J_{\mathrm{HH}}=7.7,13.3 \mathrm{~Hz}, 2 \mathrm{H}, \mathrm{H}^{3,5}\left(\mathrm{C}_{6} \mathrm{H}_{5}\right)\right]$. ${ }^{13} \mathrm{C}\left\{{ }^{1} \mathrm{H}\right\}$ NMR $\left(151 \mathrm{MHz}, \mathrm{CDCl}_{3}, 298 \mathrm{~K}\right): \delta_{\mathrm{C}}=10.9\left(\mathrm{~d},{ }^{1} J_{\mathrm{PC}}=57.8\right.$, $\left.\mathrm{PCH}_{3}\right), 12.9,13.0,15.6,17.3\left(\mathrm{pzCH}_{3}\right), 107.8,108.3(\mathrm{pzCH}), 122.1$ $\left[\mathrm{d},{ }^{1} J_{\mathrm{CP}}=88.2, \mathrm{C}^{1}\left(\mathrm{C}_{6} \mathrm{H}_{5}\right)\right], 130.6\left[\mathrm{~d},{ }^{2} J_{\mathrm{CP}}=12.9, \mathrm{C}^{2,6}\left(\mathrm{C}_{6} \mathrm{H}_{5}\right)\right], 131.1$ $\left[d,{ }^{3} J_{C P}=10.6, C^{3,5}\left(C_{6} H_{5}\right)\right], 134.7\left[d,{ }^{4} J_{C P}=2.9, C^{4}\left(C_{6} H_{5}\right)\right], 146.4$, $147.2,151.4,153.4\left[\mathrm{C}^{3,5}(\mathrm{pz})\right], 228.8\left(\mathrm{CO},{ }^{1} J_{\mathrm{WC}}=158.6,{ }^{3} J_{\mathrm{CP}}=2.9\right)$, $246.9\left(\mathrm{~W} \equiv \mathrm{C},{ }^{1} \mathrm{JWC}_{\mathrm{WC}}=205.4 \mathrm{~Hz}\right) .{ }^{31} \mathrm{P}\left\{{ }^{1} \mathrm{H}\right\} \mathrm{NMR}\left(162 \mathrm{MHz} \mathrm{CDCl}_{3}, 298\right.$ $\mathrm{K}): \delta_{\mathrm{P}}=-144.3\left(\mathrm{PF}_{6}\right), 13.3\left(\mathrm{WCP},{ }^{2} J_{\mathrm{WP}}=162 \mathrm{~Hz}\right)$.

Synthesis of $\left[\mathrm{WAu}\left(\mu-\mathrm{CPPhMe}_{2}\right) \mathrm{Cl}(\mathrm{CO})_{2}\left(\mathrm{Tp}^{*}\right)\right]\left[\mathrm{PF}_{6}\right][4] \mathrm{PF}_{6}$. To a mixture of [1a]PF $(0.200 \mathrm{~g}, 0.240 \mathrm{mmol})$ and [AuCl(THT)] ( $0.100 \mathrm{~g}, 0.312 \mathrm{mmol}$ ) was added $\mathrm{CH}_{2} \mathrm{Cl}_{2}(10 \mathrm{~mL})$. The mixture was stirred in the absence of light for 2 hours and then loaded directly onto a silica gel column. This was eluted first with DCM, gradually increasing to $2: 1 \mathrm{v} / \mathrm{v}$ acetonitrile $/ \mathrm{CH}_{2} \mathrm{Cl}_{2}$ to elute a redpurple band. The solvent was removed under reduced pressure and the residue was dried in vacuo to give [4] $\mathrm{PF}_{6}$ as a microcrystalline red-purple solid $(0.247 \mathrm{~g}, 0.232 \mathrm{mmol}, 97 \%)$. The compound is unstable in solution, even with the exclusion of oxygen and light, decomposing with gradual deposition of a gold mirror over 18 hours. The identities of the decomposition products were not investigated however ' $\mathrm{AuCl}$ ' adducts of tungsten carbyne complexes have been previously found to involve oxidative chlorination of the tungsten centre. ${ }^{17 q}$ IR $\left(\mathrm{CH}_{2} \mathrm{Cl}_{2}, \mathrm{~cm}^{-1}\right)$ : 2037s, $1961 \mathrm{~s} v_{\text {co. }}{ }^{1} \mathrm{H}$ NMR $\left(700 \mathrm{MHz} \mathrm{CDCl}_{3}, 298\right.$ $\mathrm{K}): \delta_{\mathrm{H}}=2.19\left(\mathrm{~s}, 6 \mathrm{H}, \mathrm{pzCH}_{3}\right), 2.33\left(\mathrm{~s}, 3 \mathrm{H}, \mathrm{pzCH}_{3}\right), 2.39(\mathrm{~s}, 6 \mathrm{H}$, $\left.\mathrm{pzCH}_{3}\right), 2.45\left(\mathrm{~s}, 3 \mathrm{H}, \mathrm{pzCH}_{3}\right), 2.56\left(\mathrm{~d},{ }^{2} J_{\mathrm{PH}}=13.3,6 \mathrm{H}, \mathrm{PCH}_{3}\right), 6.01$ $(\mathrm{s}, 2 \mathrm{H}, \mathrm{pzCH}), 6.02(\mathrm{~s}, 1 \mathrm{H}, \mathrm{pzCH}), 7.70\left[\mathrm{t},{ }^{3} J_{\mathrm{HH}}=6.7,2 \mathrm{H}\right.$, $\left.\mathrm{H}^{2,6}\left(\mathrm{C}_{6} \mathrm{H}_{5}\right)\right], 7.78\left[\mathrm{t},{ }^{3}{ }_{\mathrm{HH}}=7.4,1 \mathrm{H}, \mathrm{H}^{4}\left(\mathrm{C}_{6} \mathrm{H}_{5}\right)\right], 7.99\left[\mathrm{dd},{ }^{3} J_{\mathrm{HH}}=13.3\right.$, $\left.7.8 \mathrm{~Hz}, 2 \mathrm{H}, \mathrm{H}^{3,5}\left(\mathrm{C}_{6} \mathrm{H}_{5}\right)\right] .{ }^{13} \mathrm{C}\left\{{ }^{1} \mathrm{H}\right\} \mathrm{NMR}\left(176 \mathrm{MHz}, \mathrm{CDCl}_{3}, 298 \mathrm{~K}\right): \delta_{\mathrm{c}}$ $=10.9\left(\mathrm{~d},{ }^{1} J_{\mathrm{PC}}=58.5, \mathrm{PCH}_{3}\right), 12.7,13.3,16.1,17.4\left(\mathrm{pzCH}_{3}\right), 108.7$, $109.7(\mathrm{pzCH}), 120.6\left[\mathrm{~d},{ }^{1} J_{\mathrm{CP}}=88.4, \mathrm{C}^{1}\left(\mathrm{C}_{6} \mathrm{H}_{5}\right)\right], 130.7\left[\mathrm{~d},{ }^{2} J_{\mathrm{CP}}=13.0\right.$, $\left.\mathrm{C}^{2,6}\left(\mathrm{C}_{6} \mathrm{H}_{5}\right)\right], 131.3\left[\mathrm{~d},{ }^{3} \mathrm{~J}_{\mathrm{CP}}=10.6 \mathrm{~Hz}, \mathrm{C}^{3,5}\left(\mathrm{C}_{6} \mathrm{H}_{5}\right)\right], 135.4\left[\mathrm{C}^{4}\left(\mathrm{C}_{6} \mathrm{H}_{5}\right)\right]$, $147.3,148.1,152.4,154.5\left(\mathrm{pzC}^{3,5} \mathrm{CH}_{3}\right), 214.0\left(\mathrm{CO},{ }^{1} J_{\mathrm{WC}}=152.2\right)$, $233.9\left(\mathrm{~d},{ }^{1} J_{\mathrm{CP}}=31.8 \mathrm{~Hz}, \mathrm{~W}=\mathrm{C}\right) .{ }^{31} \mathrm{P}\left\{{ }^{1} \mathrm{H}\right\} \mathrm{NMR}\left(162 \mathrm{MHz}, \mathrm{CDCl}_{3}, 298\right.$ $\mathrm{K}): \delta_{\mathrm{P}}=-144.3\left(\mathrm{PF}_{6}\right), 29.0\left({ }^{2} J_{\mathrm{WP}}=96.4 \mathrm{~Hz}, \mathrm{WCP}\right) . \mathrm{MS}(\mathrm{ESI}, \mathrm{m} / z)$ : Found: 919.1324. Calcd for $\mathrm{C}_{26} \mathrm{H}_{33} \mathrm{Au}^{11} \mathrm{~B}^{35} \mathrm{ClN}_{6} \mathrm{O}_{2} \mathrm{P}^{184} \mathrm{~W}\left[\mathrm{M}-\mathrm{PF}_{6}\right]^{+}$: 919.1358. Anal. Found: C, 29.44; H, 3.04; N, 7.75\%. Calcd for $\mathrm{C}_{26} \mathrm{H}_{33} \mathrm{AuBClF}_{6} \mathrm{~N}_{6} \mathrm{O}_{2} \mathrm{P}_{2} \mathrm{~W}: \mathrm{C}, 29.33 ; \mathrm{H}, 3.12 ; \mathrm{N}, 7.89 \%$. Single crystals suitable for $\mathrm{X}$-ray structure diffraction were grown by slow evaporation of a dichloromethane/hexane mixture. Crystal data for $\mathrm{C}_{26} \mathrm{H}_{33} \mathrm{AuBClF}_{6} \mathrm{~N}_{6} \mathrm{O}_{2} \mathrm{P}_{2} \mathrm{~W} \quad\left(M_{\mathrm{w}}=1064.60 \mathrm{gmol}^{-1}\right)$ : orthorhombic, space group $P$ bca (no. 61), $a=12.2679(5) \AA$, $b=$ 24.0778(19) $\AA, c=24.2183(8) \AA, V=7153.7(7) \AA^{3}, Z=8, T=$ $150.0(1) \mathrm{K}, \mu($ Mo K $\alpha)=7.539 \mathrm{~mm}^{-1}, D_{\text {calc }}=1.977 \mathrm{Mgm}^{-3}, 17300$ reflections measured $\left(6.93^{\circ} \leq 2 \Theta \leq 56.83^{\circ}\right), 7351$ unique $\left(R_{\text {int }}=\right.$ $0.0534, R_{\text {sigma }}=0.0771$ ) which were used in all calculations. The 
final $R_{1}$ was $0.0669(I>2 \sigma(I))$ and $w R_{2}$ was 0.1760 (all data) for 415 refined parameters with 12 restraints.

Synthesis of $\left[\mathrm{W}_{2} \mathrm{Cu}_{2}\left(\mu-\mathrm{CPPhMe}_{2}\right)(\mu-\mathrm{Cl})_{2}(\mathrm{CO})_{4}\left(\mathrm{Tp}^{*}\right)_{2}\right]\left[\mathrm{PF}_{6}\right]_{2}$ [5][PF $]_{2}$. To a mixture of [1a]PF $6(0.050 \mathrm{~g}, 0.060 \mathrm{mmol})$ and [CuCl(SMe $)$ ] $(0.010 \mathrm{~g}, 0.062 \mathrm{mmol})$ was added $\mathrm{CH}_{2} \mathrm{Cl}_{2}(10 \mathrm{~mL})$. The mixture was stirred in the absence of light for 2 hours and then loaded directly onto a silica gel chromatography column and eluted initially with DCM, gradually increasing to $2: 1 \mathrm{v} / \mathrm{v}$ acetonitrile $/ \mathrm{CH}_{2} \mathrm{Cl}_{2}$. Volatiles were removed under reduced pressure and the residue was dried in vacuo to give [5] $\left[\mathrm{PF}_{6}\right]_{2}$ as a microcrystalline red solid $(0.054 \mathrm{~g}, 0.058 \mathrm{mmol}, 97 \%)$. IR $\left(\mathrm{CH}_{2} \mathrm{Cl}_{2}, \mathrm{~cm}^{-1}\right): 2024 \mathrm{~s}$, 1947s vco. ${ }^{1} \mathrm{H}$ NMR $\left(700 \mathrm{MHz}, \mathrm{CDCl}_{3}, 298\right.$ $\mathrm{K}): \delta_{\mathrm{H}}=2.22\left(\mathrm{~s} . \mathrm{br}, 6 \mathrm{H}, \mathrm{PMe}{ }_{2} \mathrm{Ph}\right), 2.29(\mathrm{~s}, 9 \mathrm{H}, \mathrm{pzCH}$ ), $2.31(\mathrm{~s}, 3$ $\left.\mathrm{H}, \mathrm{pzCH} \mathrm{CH}_{3}\right), 2.38\left(\mathrm{~s}, 6 \mathrm{H}, \mathrm{pzCH} \mathrm{CH}_{3}\right), 5.90(\mathrm{~s}, 1 \mathrm{H}, \mathrm{pzCH}), 5.99(\mathrm{~s}, 2 \mathrm{H}$, $\mathrm{pzCH}), 7.64\left[\mathrm{td},{ }^{3} \mathrm{JHH}_{\mathrm{HH}}=7.8,3.2,2 \mathrm{H}, \mathrm{H}^{2,6}\left(\mathrm{C}_{6} \mathrm{H}_{5}\right)\right], 7.73\left[\mathrm{t},{ }^{3} J_{\mathrm{HH}}=7.3\right.$, $\left.1 \mathrm{H}, \mathrm{H}^{4}\left(\mathrm{C}_{6} \mathrm{H}_{5}\right)\right], 7.84\left[\mathrm{dd},{ }^{3} \int_{\mathrm{HH}}=13.1,8.0 \mathrm{~Hz}, 2 \mathrm{H}, \mathrm{H}^{3,5}\left(\mathrm{C}_{6} \mathrm{H}_{5}\right)\right]$. ${ }^{13} \mathrm{C}\left\{{ }^{1} \mathrm{H}\right\}$ NMR $\left(176 \mathrm{MHz}, \mathrm{CDCl}_{3}, 298 \mathrm{~K}\right): \delta_{\mathrm{C}}=11.1(\mathrm{~d}, 1 \mathrm{JPC}=57.8$, $\left.\mathrm{PCH}_{3}\right), 12.7,13.0,13.1,15.56,15.63,17.4,17.5\left(\mathrm{pzCH}_{3}\right), 108.1$ (br, pzCH), $122.8\left[\mathrm{~d},{ }^{1} J_{\mathrm{CP}}=75.6 \mathrm{~Hz}, \mathrm{C}^{1}\left(\mathrm{C}_{6} \mathrm{H}_{5}\right)\right], 130.0-130.6[\mathrm{~m}$, $\left.\mathrm{C}^{2,6}\left(\mathrm{C}_{6} \mathrm{H}_{5}\right)\right], 131.2-131.8\left[\mathrm{~m}, \mathrm{C}^{3,5}\left(\mathrm{C}_{6} \mathrm{H}_{5}\right)\right], 134.8\left[\mathrm{~d},{ }^{4} \mathrm{JP}_{\mathrm{CP}}=13.9 \mathrm{~Hz}\right.$, $\left.\mathrm{C}^{4}\left(\mathrm{C}_{6} \mathrm{H}_{5}\right)\right], 146.2\left[1 \mathrm{C}, \mathrm{C}^{3,5}(\mathrm{pz})\right], 147.4\left[\mathrm{v} . \mathrm{br}, 2 \mathrm{C}, \mathrm{C}^{3,5}(\mathrm{pz})\right], 151.3[1$ $\left.\mathrm{C}, \mathrm{C}^{3,5}(\mathrm{pz})\right], 153.5$ [v.br, $\left.2 \mathrm{C}, \mathrm{C}^{3,5}(\mathrm{pz})\right], 218.1$ (br, wCO) (bm, cO). The carbyne resonance was not unambiguously identified. Pyrazolyl ring resonances displayed an unusual set of resonances in that while those for the $\mathrm{C}^{4}$ carbon nuclei appear as an unresolved broad multiplet, those for the $\mathrm{C}^{3,5}$ carbons comprise one sharp pair of resonances corresponding to a single pyrazolyl while those for the remaining two pyrazolyls are broad multiplets with apparent but unresolved fine-structure. We attribute this to ion pairing involving nestling of each $\mathrm{PF}_{6}{ }^{-}$ counter anions between two pyrazolyls, a situation favoured by the compound being a 1:2 electrolyte. ${ }^{31} \mathrm{P}\left\{{ }^{1} \mathrm{H}\right\} \mathrm{NMR}(162 \mathrm{MHz}$, $\left.\mathrm{CDCl}_{3}, 298 \mathrm{~K}\right): \delta_{\mathrm{p}}=-144.2\left(\mathrm{PF}_{6}\right), 26.1(\mathrm{WCP}) . \mathrm{MS}(\mathrm{ESI}, \mathrm{m} / \mathrm{z})$ : Found: 785.1058. Calcd for $\mathrm{C}_{26} \mathrm{H}_{33}{ }^{11} \mathrm{~B}^{35} \mathrm{Cl}^{63} \mathrm{CuN}_{6} \mathrm{O}_{2} \mathrm{P}^{184} \mathrm{~W}$ [M$\left.\mathrm{PF}_{6}\right]^{+}$: 785.0980. Anal. Found: $\mathrm{C}, 33.57 ; \mathrm{H}, 3.48 ; \mathrm{N}, 8.97 \%$. Calcd for $\mathrm{C}_{52} \mathrm{H}_{66} \mathrm{~B}_{2} \mathrm{Cl}_{2} \mathrm{Cu}_{2} \mathrm{~F}_{12} \mathrm{~N}_{12} \mathrm{O}_{4} \mathrm{P}_{4} \mathrm{~W}_{2}$ : C, 33.54; $\mathrm{H}, 3.57 ; \mathrm{N}, 9.03 \%$. Single crystals suitable for $\mathrm{X}$-ray structure diffraction were grown by slow evaporation of a dichloromethane/hexane mixture. Crystal data for $\mathrm{C}_{26} \mathrm{H}_{33} \mathrm{BClCuF}_{6} \mathrm{~N}_{6} \mathrm{O}_{2} \mathrm{P}_{2} \mathrm{~W}\left(M_{\mathrm{w}}=931.17\right.$ gmol $^{-1}$ ): triclinic, space group $P-1$ (no. 2), $a=13.3582(8) \AA$, $b=$ $16.9977(10) \AA, c=17.9256(11) \AA, \alpha=111.350(6)^{\circ}, b=$ 100.699(5) $)^{\circ}, v=90.294(5)^{\circ}, V=\quad 3713.2(4) \AA^{3}, Z=\quad 4, T=$ $150.0(1) \mathrm{K}, \mu(\mathrm{Cu} \mathrm{K \alpha})=8.381 \mathrm{~mm}^{-1}, D_{\text {calc }}=1.666 \mathrm{Mgm}^{-3}, 20370$ reflections measured $\left(7.76^{\circ} \leq 2 \Theta \leq 141.12^{\circ}\right), 13639$ unique $\left(R_{\text {int }}=0.0582, \quad R_{\text {sigma }}=0.0928\right)$ which were used in all calculations. The final $R_{1}$ was $0.0797(I>2 \sigma(I))$ and $w R_{2}$ was 0.2025 (all data) for 847 refined parameters with 142 restraints. A solvent mask was calculated and 120 electrons were found in a volume of $547 \AA^{3}$ in 2 voids per unit cell. This is consistent with the presence of $2\left[\mathrm{CHCl}_{3}\right]$ per asymmetric unit which account for 464 electrons per unit cell.

Synthesis of $\left[\mathrm{WPt}(\mu-\mathrm{CPPhMe})\left(\eta^{4}-\mathrm{COD}\right)(\mathrm{CO})_{2}\left(\mathrm{Tp}^{*}\right)\right]\left[\mathrm{PF}_{6}\right]$ [6][PF 6 . To a mixture of [1a]PF $(0.100 \mathrm{~g}, 0.120 \mathrm{mmol})$ and [Pt(nbe) $)_{3}$ (0.080 g, $\left.0.168 \mathrm{mmol}\right)$ was added $\mathrm{CH}_{2} \mathrm{Cl}_{2}(5 \mathrm{~mL})$ and 1,5 -cyclo-octadiene ( 2 drops, in excess). The solution rapidly darkened and was stirred for three hours after which more $\left[\mathrm{Pt}(\mathrm{nbe})_{3}\right](0.020 \mathrm{mg}, 0.042 \mathrm{mmol})$ was added. Stirring was continued for a further two hours. The reaction mixture was loaded directly onto a silica gel column and eluted in DCM, gradually increasing to $5: 1 \mathrm{v} / \mathrm{v}$ acetonitrile $/ \mathrm{CH}_{2} \mathrm{Cl}_{2}$. A yellow band was collected and solvent was removed under reduced pressure. The residue was further dried in vacuo to give [6][ $\left.\mathrm{PF}_{6}\right]$ as a yellow-brown solid $(0.064 \mathrm{mg}, 0.056 \mathrm{mmol}, 47 \%)$. IR $\left(\mathrm{CH}_{2} \mathrm{Cl}_{2}, \mathrm{~cm}^{-1}\right)$ : 2037s, $1960 \mathrm{~s} \mathrm{v}_{\mathrm{co}}{ }^{1} \mathrm{H}$ NMR $\left(700 \mathrm{MHz}, \mathrm{CDCl}_{3}, 298\right.$ $\mathrm{K}): \delta_{\mathrm{H}}=1.46\left(\mathrm{~d}, 6 \mathrm{H},{ }^{2} J_{\mathrm{PH}}=12.6, \mathrm{PCH}_{3}\right), 1.47\left(\mathrm{~s}, 3 \mathrm{H}, \mathrm{PMe} e_{2} \mathrm{Ph}\right)$, $\left.1.94(\mathrm{~s}, 6 \mathrm{H}, \mathrm{pzCH})_{3}\right), 2.29\left(\mathrm{~s}, 3 \mathrm{H}, \mathrm{pzCH}_{3}\right), 2.33\left(\mathrm{~m}, 2 \mathrm{H}, \mathrm{COD} \mathrm{CH} \mathrm{CH}_{2}\right.$, $2.46\left(\mathrm{~m}, 2 \mathrm{H}, \mathrm{COD} \mathrm{CH} \mathrm{C}_{2}\right), 2.50(\mathrm{~s}, 6 \mathrm{H}, \mathrm{pzCH}), 2.54\left(\mathrm{~s}, 3 \mathrm{H}, \mathrm{pzCH}_{3}\right)$, $2.57\left(\mathrm{~m}, 2 \mathrm{H}, \mathrm{COD} \mathrm{CH}_{2}\right), 2.68\left(\mathrm{~m}, 2 \mathrm{H}, \mathrm{COD} \mathrm{CH}_{2}\right), 5.06(\mathrm{~m}, 2 \mathrm{H}$, COD CH), $5.54(\mathrm{~m}, 2 \mathrm{H}, \mathrm{COD} \mathrm{CH}), 5.80(\mathrm{~s}, 1 \mathrm{H}, \mathrm{pzCH}), 5.89(\mathrm{~s}, 2 \mathrm{H}$, $\mathrm{pzCH}), 7.31$ [ddd, $\left.{ }^{3} \mathrm{~J}_{\mathrm{HH}}=12.5,8.2,1.3,2 \mathrm{H}, \mathrm{H}^{3,5}\left(\mathrm{C}_{6} \mathrm{H}_{5}\right)\right], 7.45[\mathrm{td}$, $\left.3 J_{\mathrm{HH}}=7.8,3.0,2 \mathrm{H}, \mathrm{H}^{2,6}\left(\mathrm{C}_{6} \mathrm{H}_{5}\right)\right], 7.56[\mathrm{td}, J=7.5,1.6 \mathrm{~Hz}, 1 \mathrm{H}$, $\left.\mathrm{H}^{4}\left(\mathrm{C}_{6} \mathrm{H}_{5}\right)\right] .{ }^{13} \mathrm{C}\left\{{ }^{1} \mathrm{H}\right\} \mathrm{NMR}\left(176 \mathrm{MHz}, \mathrm{CDCl}_{3}, 298 \mathrm{~K}\right): \delta_{\mathrm{C}}=11.8\left(\mathrm{~d},{ }^{1} \mathrm{JC}_{\mathrm{PC}}\right.$ $\left.=57.6, \mathrm{PCH}_{3}\right), 13.0,13.2,15.4,18.3\left(\mathrm{pzCH}_{3}\right), 29.1,32.2(\mathrm{COD}$ $\left.\mathrm{CH}_{2}\right), 89.5\left(\mathrm{COD} \mathrm{CH},{ }^{1} J_{\mathrm{CPt}}=126.7\right), 108.1,108.2\left[\mathrm{C}^{4}(\mathrm{pz}), 109.0\right.$ $\left(\mathrm{COD} C \mathrm{CH},{ }^{1} J_{\mathrm{CPt}}=96.8\right), 126.0\left[\mathrm{~d},{ }^{1} J_{\mathrm{CP}}=81.0 \mathrm{~Hz}, \mathrm{C}^{1}\left(\mathrm{C}_{6} \mathrm{H}_{5}\right)\right], 129.9$ $\left[\mathrm{d},{ }^{2} J_{\mathrm{CP}}=11.6, \mathrm{C}^{2,6}\left(\mathrm{C}_{6} \mathrm{H}_{5}\right)\right], 130.6\left[\mathrm{~d},{ }^{3} J_{\mathrm{CP}}=10.0, \mathrm{C}^{3,5}\left(\mathrm{C}_{6} \mathrm{H}_{5}\right)\right], 133.3$ $\left[\mathrm{d},{ }^{4} J_{\mathrm{CP}}=3.1, \mathrm{C}^{4}\left(\mathrm{C}_{6} \mathrm{H}_{5}\right)\right], 146.2,146.4,152.2,154.4\left[\mathrm{C}^{3,5}(\mathrm{pz})\right]$, $227.5\left(\mathrm{CO},{ }^{1} J_{\mathrm{WC}}=146.1\right), 272.8\left(\mathrm{~d},{ }^{1} J_{\mathrm{CP}}=6.0 \mathrm{~Hz},{ }^{1} J_{\mathrm{WC}}=135.1,{ }^{1} J_{\mathrm{CPt}}\right.$ $=942.2 \mathrm{~Hz}, \mathrm{~W}=C) .{ }^{31} \mathrm{P} \mathrm{NMR}\left(162 \mathrm{MHz}, \mathrm{CDCl}_{3}, 298 \mathrm{~K}\right): \delta_{\mathrm{P}}=-144.4$ $\left(\mathrm{m}, P \mathrm{~F}_{6}\right), 14.2\left({ }^{2} J_{\mathrm{WP}}=71.3 \mathrm{~Hz},{ }^{2} \mathrm{~J}_{\mathrm{PtP}}=193.4{ }^{2} J_{\mathrm{PH}}=12.1 \mathrm{~Hz}, \mathrm{WCP}\right)$. ${ }_{195} \mathrm{Pt}$ NMR $\left(86 \mathrm{MHz}, \mathrm{CDCl}_{3}, 298 \mathrm{~K}\right): \delta_{\mathrm{Pt}}=-3587$. MS $(\mathrm{ESI}, \mathrm{m} / \mathrm{z})$ : Found: 989.2566. Calcd for $\mathrm{C}_{34} \mathrm{H}_{45}{ }^{11} \mathrm{BN}_{6} \mathrm{O}_{2} \mathrm{P}^{194} \mathrm{Pt}^{184} \mathrm{~W}$ [M-PF $]^{+}$: 989.2582. Anal. Found: C, 35.86; H, 4.05; N, 7.31\%. Calcd for $\mathrm{C}_{34} \mathrm{H}_{45} \mathrm{BF}_{6} \mathrm{~N}_{6} \mathrm{O}_{2} \mathrm{P}_{2} \mathrm{PtW}$ : C, 35.97; $\mathrm{H}, 3.99 ; \mathrm{N}, 7.40 \%$. Single crystals suitable for $\mathrm{X}$-ray diffractometry were grown by slow evaporation of a dichloromethane/hexane mixture. Crystal data for $\mathrm{C}_{34} \mathrm{H}_{45} \mathrm{BF}_{6} \mathrm{~N}_{6} \mathrm{O}_{2} \mathrm{P}_{2} \mathrm{PtW} \quad\left(M_{\mathrm{w}}=1135.45 \mathrm{gmol}^{-1}\right)$ : monoclinic, space group $P 2_{1} / c$ (no. 14), $a=15.0989$ (4) $\AA$, $b=$ 23.4132(6) $\AA, c=\quad 24.3451(8) \AA, b=\quad 101.691(3)^{\circ}, V=$ $8427.8(4) \AA^{3}, Z=8, T=150.0(1) \mathrm{K}, \mu($ Mo $K \alpha)=6.183 \mathrm{~mm}^{-}$ $1, D_{\text {calc }}=1.790 \mathrm{Mgm}^{-3}, 35063$ reflections measured $\left(6.53^{\circ} \leq 2 \Theta \leq\right.$ $\left.58.62^{\circ}\right), 19108$ unique $\left(R_{\text {int }}=0.0502, R_{\text {sigma }}=0.1054\right)$ which were used in all calculations. The final $R_{1}$ was $0.0598(/>2 \sigma(/))$ and $w R_{2}$ was 0.1258 (all data) for 917 refined parameters without restraints. The solvent masking procedure as implemented in Olex2 was used to remove the electronic contribution of solvent molecules from the refinement. As the exact solvent content cannot be modelled, only the atoms used in the refinement model are reported in the formula here. Total solvent accessible volume $/$ cell $=1007.2 \AA^{3}$ [12.0\%]. Total electron count $/$ cell $=178.2$.

Synthesis of $\left[\mathrm{WPt}\left(\mu-\mathrm{CPPhMe}_{2}\right)\left(\mathrm{CN}^{t} \mathrm{Bu}\right)(\mathrm{CO})_{2}\left(\mathrm{Tp}^{*}\right)\right]\left[\mathrm{PF}_{6}\right]$ [7] $\mathrm{PF}_{6}$. To a mixture of [6]PF $6(0.020 \mathrm{~g}, 0.018 \mathrm{mmol})$ and $\mathrm{CN}^{t} \mathrm{Bu}$ (2-3 drops, excess) was added $\mathrm{CH}_{2} \mathrm{Cl}_{2}(5 \mathrm{~mL})$. The solution was stirred for three hours, after which time the solvent was removed under reduced pressure. The residue was loaded onto a silica gel column and eluted in DCM, gradually increasing to $1: 4 \mathrm{v} / \mathrm{v}$ acetonitrile $/ \mathrm{CH}_{2} \mathrm{Cl}_{2}$. A yellow band was collected and solvent was removed under reduced pressure to give [7] $\mathrm{PF}_{6}$ as a yellow-brown solid (0.017 mg, $0.014 \mathrm{mmol}, 81 \%)$. IR $\left(\mathrm{CH}_{2} \mathrm{Cl}_{2}\right.$, $\left.\mathrm{cm}^{-1}\right)$ : 2190s, 2157s $v_{\mathrm{CN}}$. 1934vs, 1846vs $v_{\mathrm{CO}} .{ }^{1} \mathrm{H}$ NMR $(700 \mathrm{MHz}$, $\left.\mathrm{CDCl}_{3}, 298 \mathrm{~K}\right): \delta_{\mathrm{H}}=1.33\left(\mathrm{~d}, 6 \mathrm{H},{ }^{2} \mathrm{JHH}_{\mathrm{PH}}=12.6, \mathrm{PCH}_{3}\right), 1.35(\mathrm{~s}, 9 \mathrm{H}$, $\left.\mathrm{CCH}_{3}\right), 1.72\left(\mathrm{~s}, 9 \mathrm{H}, \mathrm{CCH}_{3}\right), 1.75\left(\mathrm{~s}, 6 \mathrm{H}, \mathrm{pzCH}_{3}\right), 2.31(\mathrm{~s}, 3 \mathrm{H}$, $\left.\mathrm{pzCH}_{3}\right), 2.49\left(\mathrm{~s}, 6 \mathrm{H}, \mathrm{pzCH} \mathrm{CH}_{3}\right), 2.60\left(\mathrm{~s}, 3 \mathrm{H}, \mathrm{pzCH}_{3}\right), 5.79(\mathrm{~s}, 1 \mathrm{H}$, 
$\mathrm{pzCH}), 5.82(\mathrm{~s}, 2 \mathrm{H}, \mathrm{pzCH}), 7.45\left[\mathrm{td}, 3{ }_{\mathrm{HH}}=7.8,2.9,2 \mathrm{H}\right.$, $\left.\mathrm{H}^{2,6}\left(\mathrm{C}_{6} \mathrm{H}_{5}\right)\right], 7.53\left[\mathrm{~d}, 3 \mathrm{~J}_{\mathrm{HH}}=8.6,1 \mathrm{H}, \mathrm{H}^{4}\left(\mathrm{C}_{6} \mathrm{H}_{5}\right)\right], 7.66\left[\mathrm{dd},{ }^{3} J_{\mathrm{HH}}=\right.$ 12.0, $\left.7.4 \mathrm{~Hz}, 2 \mathrm{H}, \mathrm{H}^{3,5}\left(\mathrm{C}_{6} \mathrm{H}_{5}\right)\right] .{ }^{13} \mathrm{C}\left\{{ }^{1} \mathrm{H}\right\} \mathrm{NMR}\left(176 \mathrm{MHz} \mathrm{CDCl}_{3}, 298\right.$ $\mathrm{K}): \delta_{\mathrm{C}}=12.5\left(\mathrm{~d},{ }^{00} \mathrm{JPC}_{\mathrm{PC}}=58.3, \mathrm{PCH}_{3}\right), 12.8,13.0,15.2,17.7\left(\mathrm{pzCH}_{3}\right)$, 30.0, $30.8\left(\mathrm{CMe}_{3}\right)$, 58.3, 58.6 $\left(\mathrm{CMe}_{3}\right), 107.5,107.9$ [C $\left.\mathrm{C}^{4}(\mathrm{pz})\right], 125.4$ $\left[\mathrm{d},{ }^{1} J_{\mathrm{CP}}=81.1, \mathrm{C}^{1}\left(\mathrm{C}_{6} \mathrm{H}_{5}\right)\right], 129.2\left[\mathrm{~d},{ }^{2} J_{\mathrm{CP}}=11.8 \mathrm{~Hz}, \mathrm{C}^{2,6}\left(\mathrm{C}_{6} \mathrm{H}_{5}\right)\right]$, $131.4\left[\mathrm{~d},{ }^{3} J_{\mathrm{CP}}=9.4, \mathrm{C}^{3,5}\left(\mathrm{C}_{6} \mathrm{H}_{5}\right)\right], 132.6\left[\mathrm{~d},{ }^{4} J_{\mathrm{CP}}=3.4, \mathrm{C}^{4}\left(\mathrm{C}_{6} \mathrm{H}_{5}\right)\right]$, 137.9, 138.4 (PtCN), 145.5, 145.9, 152.0, 154.2 [C $\left.\mathrm{C}^{3,5}(\mathrm{pz})\right], 227.8$ $\left(C O,{ }^{2} J_{\mathrm{CPt}}=38.4,{ }^{1} J_{\mathrm{WC}}=148.7 \mathrm{~Hz}\right), 269.3\left(\mathrm{~d},{ }^{1} J_{\mathrm{CP}}=14.2,{ }^{1} J_{\mathrm{CPt}}=\right.$ $800.9 \mathrm{~Hz}, \mathrm{~W}=\mathrm{C}) .{ }^{31} \mathrm{P} \mathrm{NMR}\left(283 \mathrm{MHz}, \mathrm{CDCl}_{3}, 298 \mathrm{~K}\right): \delta_{\mathrm{p}}=-144.4$ (hept., $\left.P F_{6}\right), 17.4\left({ }^{2} J_{\mathrm{WP}}=68.7,{ }^{2} \mathrm{~J}_{\mathrm{PtP}}=164.1 \mathrm{~Hz}, \mathrm{WCP}\right) .{ }^{195} \mathrm{Pt} \mathrm{NMR}$ $\left(150 \mathrm{MHz}, \mathrm{CDCl}_{3}, 298 \mathrm{~K}\right): \delta_{\mathrm{Pt}}=-3953$. MS $(\mathrm{ESI}, \mathrm{m} / z)$ : Found: 1047.3125. Calcd for $\mathrm{C}_{36} \mathrm{H}_{51}{ }^{11} \mathrm{BN}_{8} \mathrm{O}_{2} \mathrm{P}^{194} \mathrm{Pt}^{184} \mathrm{~W}$ [M-PF $]^{+}$: 1047.3113. Anal. Found: $\mathrm{C}, 36.37 ; \mathrm{H}, 4.37 ; \mathrm{N}, 9.26 \%$. Calcd for $\mathrm{C}_{36} \mathrm{H}_{51} \mathrm{BF}_{6} \mathrm{~N}_{8} \mathrm{O}_{2} \mathrm{P}_{2} \mathrm{PtW}$ : C, 36.23; $\mathrm{H}, 4.31 ; \mathrm{N}, 9.39 \%$. Single crystals suitable for $\mathrm{X}$-ray structure diffraction were grown by slow evaporation of a dichloromethane/hexane mixture. Crystal data for $\mathrm{C}_{36} \mathrm{H}_{51} \mathrm{BF}_{6} \mathrm{~N}_{8} \mathrm{O}_{2} \mathrm{P}_{2} \mathrm{PtW} \quad\left(M_{\mathrm{w}}=1193.53 \quad \mathrm{gmol}^{-1}\right)$ : monoclinic, space group $P 2_{1} / c$ (no. 14), $a=14.6038$ (3) $\AA$, $b=$ 14.0280(3) $\AA, c=\quad 23.5934(5) \AA, b=\quad 97.914(2)^{\circ}, V=$ 4787.36(18) $\AA^{3}, Z=4, T=150.0(1) \mathrm{K}, \mu($ MoK $\alpha)=5.448 \mathrm{~mm}^{-}$ $1, D_{\text {calc }}=1.656 \mathrm{Mgm}^{-3}, 21286$ reflections measured $\left(6.59^{\circ} \leq 2 \Theta \leq\right.$ $\left.58.56^{\circ}\right), 10954$ unique $\left(R_{\text {int }}=0.0270, R_{\text {sigma }}=0.0460\right)$ which were used in all calculations. The final $R_{1}$ was $0.0301(I>2 \sigma(I))$ and $w R_{2}$ was 0.0621 (all data) for 532 refined parameters without restraints. A solvent mask was calculated and 124 electrons were found in a volume of $622 \AA^{3}$ in 1 void per unit cell. This is consistent with the presence of one ethanol per asymmetric unit which account for 104 electrons per unit cell.

Synthesis of $\left[\mathrm{W}\left\{\mathrm{Pt}(\mathrm{CNMes})_{2}\right\}(\mu-\mathrm{CPPhMe})(\mathrm{CO})_{2}\left(\mathrm{Tp}^{*}\right)\right]\left[\mathrm{PF}_{6}\right]$ [8]PF 6 . To a mixture of [6]PF 6 (0.020 g, $0.018 \mathrm{mmol})$ and 2,4,6trimethylphenyl isocyanide $(0.004 \mathrm{~g}, 0.028 \mathrm{mmol})$ was added $\mathrm{CH}_{2} \mathrm{Cl}_{2}(5 \mathrm{~mL})$. The solution was stirred for three hours, after which the solvent was removed under reduced pressure. The residue was loaded onto a silica gel column and eluted in DCM, gradually increasing to $1: 4 \mathrm{v} / \mathrm{v}$ acetonitrile $/ \mathrm{CH}_{2} \mathrm{Cl}_{2}$. A yellow band was collected and solvent was removed under reduced pressure to give [8] $\mathrm{PF}_{6}$ as a yellow-brown solid $(0.016 \mathrm{mg}, 0.012$ $\mathrm{mmol}, 69 \%)$. IR $\left(\mathrm{CH}_{2} \mathrm{Cl}_{2}, \mathrm{~cm}^{-1}\right): 2164 \mathrm{~s}, 2126 \mathrm{~s} \mathrm{v} \mathrm{CN}, 1941 \mathrm{vs}, 1853 \mathrm{vs}$ $v_{\text {co. }}{ }^{1} \mathrm{H}$ NMR $\left(700 \mathrm{MHz}, \mathrm{CDCl}_{3}, 298 \mathrm{~K}\right): \delta_{\mathrm{H}}=1.39\left(\mathrm{~d}, 6 \mathrm{H},{ }^{2} \mathrm{~J}_{\mathrm{HP}}=\right.$ $\left.12.8 \mathrm{~Hz}, \mathrm{PMe} \mathrm{e}_{2} \mathrm{Ph}\right), 1.81\left(\mathrm{~s}, 6 \mathrm{H}, \mathrm{pzCH} \mathrm{CH}_{3}, 2.21(\mathrm{~s}, 6 \mathrm{H}\right.$, mesityl o$\left.\mathrm{CH}_{3}\right), 2.29\left(\mathrm{~s}, 3 \mathrm{H}\right.$, mesityl $\left.p-\mathrm{CH}_{3}\right), 2.33(\mathrm{~s}, 3 \mathrm{H}, \mathrm{pzCH}), 2.35(\mathrm{~s}, 3$ $\mathrm{H}$, mesityl $\left.\left.p-\mathrm{CH}_{3}\right), 2.52(\mathrm{~s}, 6 \mathrm{H}, \mathrm{pzCH})_{3}\right), 2.56(\mathrm{~s}, 6 \mathrm{H}$, mesityl o$\left.\mathrm{CH}_{3}\right), 2.61\left(\mathrm{~s}, 3 \mathrm{H}, \mathrm{pzCH} \mathrm{CH}_{3}\right), 5.82(\mathrm{~s}, 1 \mathrm{H}, \mathrm{pzCH}), 5.84(\mathrm{~s}, 2 \mathrm{H}, \mathrm{pzCH})$, $6.90(\mathrm{~s}, 2 \mathrm{H}$, mesityl $\mathrm{CH}), 7.00(\mathrm{~s}, 2 \mathrm{H}$, mesityl $m-\mathrm{CH}), 7.38\left(\mathrm{t}, 3 \mathrm{~J}_{\mathrm{HH}}\right.$ $\left.=6.6 \mathrm{~Hz}, 2 \mathrm{H}, \mathrm{H}^{2,6}\left(\mathrm{C}_{6} \mathrm{H}_{5}\right)\right), 7.45\left(\mathrm{~d},{ }^{3} \mathrm{JHH}_{\mathrm{HH}}=7.3 \mathrm{~Hz}, 1 \mathrm{H}, \mathrm{H}^{4}\left(\mathrm{C}_{6} \mathrm{H}_{5}\right)\right)$, $7.70\left(\mathrm{t},{ }^{3} \mathrm{~J}_{\mathrm{HH}}=8.4 \mathrm{~Hz}, 2 \mathrm{H}, \mathrm{H}^{3,5}\left(\mathrm{C}_{6} \mathrm{H}_{5}\right)\right) .{ }^{13} \mathrm{C}\left\{{ }^{1} \mathrm{H}\right\} \mathrm{NMR}(176 \mathrm{MHz}$, $\left.\mathrm{CDCl}_{3}, 298 \mathrm{~K}\right): \delta_{\mathrm{C}}=12.7\left(\mathrm{~d}, 1 \mathrm{~J}_{\mathrm{PC}}=57.9, \mathrm{PCH}_{3}\right), 13.0,13.3,15.5$, $17.9\left(\mathrm{pzCH}_{3}\right), 19.1,19.3$ (2,6-mesityl $\mathrm{CH}_{3}$ ), 21.6, 21.7 (4-mesityl $\left.\mathrm{CH}_{3}\right), 107.8,108.2\left[\mathrm{C}^{4}(\mathrm{pz})\right], 124.8\left(\mathrm{C}_{6} \mathrm{H}_{2}\right), 125.1\left[\mathrm{C}^{1}\left(\mathrm{C}_{6} \mathrm{H}_{5}\right)\right], 125.6$, 128.6, 129.2, $129.4\left(\mathrm{C}_{6} \mathrm{H}_{2}\right), 129.5\left[\mathrm{C}^{2,6}\left(\mathrm{C}_{6} \mathrm{H}_{5}\right)\right], 131.6[\mathrm{~d}, J=9.3$, $\left.\mathrm{C}^{3,5}\left(\mathrm{C}_{6} \mathrm{H}_{5}\right)\right], 132.8\left[\mathrm{C}^{4}\left(\mathrm{C}_{6} \mathrm{H}_{5}\right)\right], 134.7,135.3,138.2,140.2\left(\mathrm{C}_{6} \mathrm{H}_{2}\right)$, 146.1, 146.3 [C $\left.\mathrm{C}^{3,5}(\mathrm{pz})\right], 150.5$ (s.br, PtCN), 152.3, 154.5 [3,5(pz)], $227.5\left(\mathrm{CO},{ }^{2} J_{\mathrm{CPt}}=43.5,1 J_{\mathrm{WC}}=150.3\right), 271.0\left(\mathrm{~d},{ }^{1} J_{\mathrm{CP}}=14.1 \mathrm{~Hz}\right.$, $\mathrm{W}=C) .{ }^{31} \mathrm{P} N M R\left(162 \mathrm{MHz}, \mathrm{CDCl}_{3}, 298 \mathrm{~K}\right): \delta_{\mathrm{p}}=-144.4\left(\mathrm{~m}, P \mathrm{~F}_{6}\right)$, $18.7\left({ }^{2} J_{\mathrm{WP}}=61.9,{ }^{2} J_{\mathrm{PtP}}=160.0 \mathrm{~Hz}, \mathrm{WCP}\right) .{ }^{195} \mathrm{Pt} \mathrm{NMR}(86 \mathrm{MHz}$, $\left.\mathrm{CDCl}_{3}, 298 \mathrm{~K}\right): \delta_{\mathrm{Pt}}=-3862.6$. MS (ESI, $\left.\mathrm{m} / z\right)$ : Found: 1172.3408 .
Calcd for $\mathrm{C}_{46} \mathrm{H}_{55}{ }^{11} \mathrm{BN}_{8} \mathrm{O}_{2} \mathrm{P}^{195} \mathrm{Pt}^{184} \mathrm{~W}$ [M-PF $]^{+}:$1172.3447. Anal. Found: C, 40.55; $\mathrm{H}, 3.14 ; \mathrm{N}, \quad 7.90 \%$. Calcd for $\mathrm{C}_{46} \mathrm{H}_{55} \mathrm{BF}_{6} \mathrm{~N}_{8} \mathrm{O}_{2} \mathrm{P}_{2} \mathrm{PtW} . \mathrm{CH}_{2} \mathrm{Cl}_{2}: \mathrm{C}, 40.25 ; \mathrm{H}, 4.10 ; \mathrm{N}, 7.99 \%$. Single crystals suitable for $\mathrm{X}$-ray crystallography were grown by slow evaporation of a chloroform/hexane mixture. Crystal data for $\mathrm{C}_{46} \mathrm{H}_{55} \mathrm{BF}_{6} \mathrm{~N}_{8} \mathrm{O}_{2} \mathrm{P}_{2} \mathrm{PtW} . \mathrm{CHCl}_{3}\left(M_{\mathrm{w}}=1437.03 \mathrm{gmol}^{-1}\right)$ : monoclinic, space group $P 2_{1} / \mathrm{c}$ (no. 14$), a=16.5808(4) \AA$, $b=$ 14.4490(4) $\AA, c=\quad 22.7627(6) \AA, b=\quad 93.001(2)^{\circ}, V=$ $5445.9(2) \AA^{3}, Z=4, T=150.0(1) \mathrm{K}, \mu($ Mo $\mathrm{K \alpha})=4.948 \mathrm{~mm}^{-}$ $1, D_{\text {calc }}=1.753 \mathrm{Mgm}^{-3}, 24477$ reflections measured $\left(6.66^{\circ} \leq 2 \Theta \leq\right.$ $\left.58.53^{\circ}\right), 12383$ unique $\left(R_{\text {int }}=0.0478, R_{\text {sigma }}=0.0884\right)$ which were used in all calculations. The final $R_{1}$ was $0.0402(I>2 \sigma(I))$ and $w R_{2}$ was 0.0699 (all data) for 646 refined parameters without restraints.

\section{Acknowledgements}

We gratefully acknowledge the Australian Research Council (DP170102695 and DP190100723) for funding. There are no conflicts to declare.

\section{Notes and references}

1. S. J. Holmes, R. R. Schrock, M. R. Churchill and H. J. Wasserman, Organometallics, 1984, 3, 476-484.

2. A. K. List, G. L. Hillhouse and A. L. Rheingold, Organometallics, 1989, 8, 2010-2016.

3. (a) X. Li, M. Schopf, J. Stephan, K. Harms and J. Sundermeyer, Organometallics, 2002, 21, 2356-2358. (b) X. Li, J. Stephan, K. Harms and J. Sundermeyer, Organometallics, 2004, 23, 33593361. (c) X. Li, M. Schopf, J. Stephan, J. Kippe, K. Harms and J. Sundermeyer, J. Am. Chem. Soc., 2004, 126, 8660-8661. (d) X. Li, H. Sun, K. Harms and J. Sundermeyer, Organometallics, 2005, 24, 4699-4701. (e) X. Li, M. Schopf, J. Stephan, J. Kipke, K. Harms and J. Sundermeyer, Organometallics, 2006, 25, 528-530. (f) X. Li, A. Wang, L. Wang, H. Sun, K. Harms and J. Sundermeyer, Organometallics, 2007, 26, 1411-1413. (g) X. Li, A. Wang, H. Sun, L. Wang, S. Schmidt, K. Harms and J. Sundermeyer, Organometallics, 2007, 26, 3456-3460. (h) F. G. Schroder, C. Lichtenberg, M. Elfferding and J. Sundermeyer, Organometallics, 2013, 32, 5082-5091. See also (i) E. B. Hulley, J. B. Bonanno, P. T. Wolczanski, T. R. Cundari and E. B. Lobkovsky, Inorg. Chem., 2010, 49, 8524-8544. (j) M. Kamitani, B. Pinter, K. Searles, M. G. Crestani, A. Hickey, B. C. Manor, P. J. Carroll and D. J., J. Am. Chem. Soc., 2015, 137, 11872-11875. (k) G. W. Rice, G. B. Ansell, M. A. Modrick and S. Zentz, Organometallics, 1983, 2, 154-157.

4. (a) H. Schmidbaur, R. Pichl and G. Müller, Angew. Chem., Int. Ed. Engl., 1986, 25, 574-575. See also (b) K. A. Hughes, P. G. Dopico, M. Sabat and M. G. Finn, Angew. Chem., Int. Ed., 1993, 32, 554555.

5. (a) G. M. Jamison P. S. White and J. L. Templeton, Organometallics, 1991, 10, 1954-1959. (b) A. E. Bruce, A. S. Gamble, T. L. Tonker and J. L. Templeton, Organometallics, 1987, 6, 1350-1352.

6. (a) A. L. Colebatch, A. F. Hill and M. Sharma, Organometallics, 2015, 34, 2165-2182. (b) A. L. Colebatch and A. F. Hill, Dalton Trans., 2017, 46, 4355-4365. 
7. A. F. Hill, M. Sharma and A. C. Willis, Organometallics, 2012, 31, 2538-2542.

8. L. K Burt, R. L Cordiner, A. F. Hill, R. A. Manzano and J. Wagler, Chem. Commun., 2020, 56, 5673-5676. (b) L. K. Burt and A. F. Hill, Dalton Trans., 2020, 49, 8143-8161.

9. (a) M. I. Bruce , M. L. Cole , M. Gaudio , B. W. Skelton and A. H. White , J. Organomet. Chem., 2006, 691, 4601-4614. (b) R. L. Cordiner , P. A. Gugger , A. F. Hill and A. C. Willis, Organometallics, 2009, 28, 6632-6635. (c) A. L. Colebatch , Y.-S. Han , A. F. Hill , M. Sharma, R. Shang and J. S. Ward, Chem. Commun., 2017, 53, 1832-1835. (d) A. L. Colebatch and A. F. Hill, J. Am. Chem. Soc., 2014, 136, 17442-17445. (e) B. J. Frogley, A. F. Hill and A. Seitz, Chem. Commun., 2020, 56, 3265-3268. (f) B. J. Frogley and A. F. Hill, Dalton Trans., 2020, 49, 3272-3283. (g) B. J. Frogley and A. F. Hill, Chem. Commun., 2019, 55, 15077-15080. (h) A. F. Hill and R. A. Manzano, Angew. Chem., Int. Ed., 2019, 58, 7357-7360. (i) A. F. Hill and R. A. Manzano, Dalton Trans., 2019, 48, 6596-6610.

10. A small number of trimetallic $\mu_{3}$-phosphoniocarbynes are known: (a) S. Ching, M. Sabat and D. F. Shriver, J. Am. Chem. Soc., 1987, 109, 4722-4723. (b) S. Ching, M. P. Jensen, M. Sabat and D. F. Shriver, Organometallics, 1989, 8, 1058-1063. (c) H. Schmidbaur, F. Scherbaum, B. Huber and G. Muller, Angew. Chem., Int. Ed., 1988, 27, 419-421. (d) B. F. G. Johnson, F. J. Lahoz, J. Lewis, N. D. Prior, P. R. Raithby and W.-T. Wong, J. Chem. Soc., Dalton Trans., 1992, 1701-1708. (e) Y.-Y. Choi, W.-Y. Wong and W.-T. Wong, J. Organomet. Chem., 1996, 518, 227-233. (f) D. S. Bohle, D. Heineke, A. Tiripicchio, M. Tiripicchio-Camellini and $\mathrm{H}$. Vahrenkamp, Angew. Chem., Int. Ed., 1990, 29, 896-898.

11. (a) F. G. A. Stone, Angew. Chem., Int. Ed. Engl., 1984, 23, 89-99. (b) R. Hoffmann, Angew. Chem., Int. Ed., 1982, 21, 711-724.

12. C. A. Tolman, Chem. Rev., 1977, 77, 313-348.

13. (a) A. E. Enriquez, P. S. White and J. L. Templeton, J. Am. Chem. Soc., 2001, 123, 4992-5002. (b) A. F. Hill and R. A. Manzano, Angew. Chem., Int. Ed., 2019, 58, 7357-7360. (c) R. L. Cordiner, A. F. Hill and J. Wagler, Organometallics, 2008, 27, 4532-4540.

14. $\boldsymbol{T R}=2 r(\mathrm{M}-\mathrm{N}$ trans $) / \Sigma r\left(\mathrm{M}-\mathrm{N}_{\mathrm{cis}}\right)$ : R. L. Cordiner, A. F. Hill, R. Shang and A. C. Willis, Organometallics, 2011, 30, 139-144.

15. S. J. Dossett, A. F. Hill, J. C. Jeffery, F. Marken, P. Sherwood, and F. G. A. Stone, J. Chem. Soc., Dalton Trans., 1988, 2453-2465.

16. The HOMO is rather invariant across the series and corresponds primarily to the orthogonal $\mathrm{W}\left(d_{\mathrm{xy}}\right)$ orbitals responsible for $\mathrm{W}-\mathrm{CO}$ $\pi$-bonding.

17. (a) G. R. Clark, C. M. Cochrane, W. R. Roper and L. J. Wright, J. Organomet. Chem., 1980, 199, C35-C38. (b) A. F. Hill, W. R. Roper, J. M. Waters and A. H. Wright, J. Am. Chem. Soc., 1983, 105, 5930-5940. (c) G. A. Carriedo, J. A. K. Howard, K. Marsden, F. G. A. Stone and P. Woodward, J. Chem. Soc., Dalton Trans., 1984, 1589-1595. (d) M. Green, J. A. K. Howard, A. P. James, C. M. Nunn and F. G. A. Stone, J. Chem. Soc., Chem. Commun., 1984, 1113-1114. (e) S. H. F. Becke, M. D. Bermúdez, N. H. Tran-Huy, J. A. K. Howard, O. Johnson and F. G. A. Stone, J. Chem. Soc., Dalton Trans., 1987, 1229-1234. (f) M. Green, J. A. K. Howard, A. P. James, C. M. Nunn and F. G. A. Stone, J. Chem. Soc., Dalton Trans., 1987, 61-72. (g) S. J. Crennell, D. D. Devore, S. J. B. Henderson, J. A. K. Howard and F. G. A. Stone, J. Chem. Soc., Dalton Trans., 1989, 1363-1374. (h) P. K. Byers, N. Carr and F. G. A. Stone, J. Chem. Soc., Dalton Trans., 1990, 3701-3708. (i) M. C. Gimeno and F. G. A. Stone, J. Chem. Soc., Dalton Trans., 1990, 2239-2245. (j) N. Carr, M. C. Gimeno and F. G. A. Stone, J. Chem. Soc., Dalton Trans., 1990, 2247-2252. (k) S. J. Dossett, I. J. Hart, M. U. Pilotti and F. G. A. Stone, J. Chem. Soc., Dalton Trans., 1990, 3489-3497.
(I) J.-L. Cabioch, S. J. Dossett, I. J. Hart, M. U. Pilotti and F. G. A. Stone, J. Chem. Soc., Dalton Trans., 1991, 519-527. (m) J. E. Goldberg, D. F. Mullica, E. L. Sappenfield and F. G. A. Stone, J. Chem. Soc., Dalton Trans., 1992, 2495-2502. (n) A. L. Colebatch and A. F. Hill, Dalton Trans., 2017, 46, 4355-4365. (o) B. J. Frogley, A. F. Hill and C. S. Onn, Dalton Trans, 2019, 48, 11715-11723. (p) B. J. Frogley and A. F. Hill, Angew. Chem., Int. Ed., 2019, 58, 80448048. (q) A. R. Delaney, B. J. Frogley and A. F. Hill, Dalton Trans., 2019, 48, 13674-13684. (r) B. J. Frogley, A. F. Hill and L. J. Watson, Chem. Commun., 2019, 55, 14450-14453.

18. V. G. Albano, L. Busetto, M. C. Cassani, P. Sabatino, A. Schmitz and V. Zanotti, J. Chem. Soc., Dalton Trans., 1995, 2087-2093.

19. (a) J. C. Jeffery, J. C. V. Laurie, I. Moore, H. Razay and F. G. A. Stone, J. Chem. Soc., Dalton Trans.,1984, 1563-1569. (b) G. A. Carriedo, J. A. K. Howard and F. G. A. Stone, J. Chem. Soc., Dalton Trans., 1984, 1555-1561. (c) G. P. Elliott, J. A. K. Howard, T. Mise, I. Moore, C. M. Nunn and F. G. A. Stone J. Chem. Soc., Dalton Trans., 1986, 2091-2103. (d) T. V. Ashworth, M. J. Chetcuti, J. A. K. Howard, F. G. A. Stone, S. J. Wisbey and P. Woodward, J. Chem. Soc., Dalton Trans., 1981, 763-770. (e) G. P. Elliott, J. A. K. Howard, T. Mise, C. M. Nunn and F. G. A. Stone, J. Chem. Soc., Dalton Trans., 1987, 2189-2200. (f) J. C. Jeffery, D. B. Lewis, G. E. Lewis, M. J. Parrott and F. G. A. Stone, J. Chem. Soc., Dalton Trans., 1986, 1717-1722. (g) S. J. Davies, J. A. K. Howard, M. U. Pilotti and F. G. A. Stone J. Chem. Soc., Dalton Trans., 1989, 22892296. (h) S. J. Davies, A. F. Hill, M. U. Pilotti and F. G. A. Stone, Polyhedron, 1989, 8, 2265-2270

20. B. J. Frogley and A. F. Hill, Chem. Commun., 2019, 55, 1240012403.

21. (a) B. J. Frogley and A. F. Hill, Angew. Chem., Int. Ed., 2019, 58, 8044-8048. (b) A. R. Delaney, B. J. Frogley and A. F. Hill, Dalton Trans., 2019, 48, 13674-13684.

22. (a) R. D. Barr, T. B. Marder, A. G. Orpen and I. D. Williams, J. Chem. Soc., Chem. Commun., 1984, 112-114; (b) F. A. Cotton, Prog. Inorg. Chem., 1976, 21, 1-28; (c) W. J. Hersh, F. J. Hollander and R. G. Bergman, J. Am. Chem. Soc., 1983, 105, 5834-5846.

23 (a) S. H. F. Becke, M. D. Bermudez, M. Dolores; N. H. Tran-Huy, J. A. K. Howard, O. Johnson and F. G. A. Stone, J. Chem. Soc., Dalton Trans., 1987, 1229-1234. (b) M. D. Bermudez, E. Delgado, G. P. Elliott, N. H. Tran-Huy, F. Mayor-Real, F. G. A. Stone and M. J. Winter, J. Chem. Soc., Dalton Trans., 1987, 1235-1242

24 M. R. St.-J. Foreman, A. F. Hill, A. J. P. White and D. J. Williams, Organometallics, 2003, 22, 3831-3840.

25 R. J. Abernethy, M. R. St.-J. Foreman, A. F. Hill, M. K. Smith and A. C. Willis, Dalton Trans., 2020, 49, 781-796.

26 K. B. Wiberg, Tetrahedron, 1968, 24, 1083-1096.

27 (a) J. Cooke and J. Takats, J. Am. Chem. Soc., 1997, 119, 1108811089. (b) R. G. Ball, M. R. Burke and J. Takats, Organometallics, 1987, 6, 1918-1924. (c) M. J. Burn, G.-Y. Kiel, F. Seils, J. Takats and J. Washington, J. Am. Chem. Soc., 1989, 111, 6850-6852. (d) M. R. Gagné and J. Takats, Organometallics, 1988, 7, 561-563. (e) J. Washington, R. MacDonald, J. Takats, N. Menashe, D. Reshef and Y. Shvo, Organometallics, 1995, 14, 3996-4003.

28 S. J. Dossett, A. F. Hill, J. A. K. Howard, B. A. Nasir, T. P. Spaniol, P. Sherwood and F. G. A. Stone, J. Chem. Soc., Dalton Trans., 1989, 1871-1878.

29 L. E. Craskall and J. L. Spencer, Inorg. Synth., 1990, 28 126-132.

30 R. Uson, A. Laguna, M. Laguna, D. Briggs, H. Murray and J. Fackler Jr, Inorg. Synth., 1989, 26, 85-91

31 E. A. Doud, M. S. Inkpen, G. Lovat, E. Montes, D. W. Paley, M. L. Steigerwald, H. Vázquez, L. Venkataraman and X. Roy, J. Am. Chem. Soc., 2018, 140, 8944-8949 
32 Agilent, CrysAlis PRO, Agilent Technologies Ltd, Yarnton, Oxfordshire, England, 2014

33 (a) G. Sheldrick, Acta Crystallogr. Sect. A: Found. Crystallogr. 2008, 64, 112-122; (b) G. M. Sheldrick, Acta Crystallogr. Sect. C: Cryst. Struct. Commun., 2015, 71, 3-8.

34 (a) C. F. Macrae, P. R. Edgington, P. McCabe, E. Pidcock, G. P. Shields, R. Taylor, M. Towler and J. van de Streek, J. Appl. Crystallogr., 2006, 39, 453-457; (b) C. F. Macrae, I. J. Bruno, J. A. Chisholm, P. R. Edgington, P. McCabe, E. Pidcock, L. RodriguezMonge, R. Taylor, J. van de Streek and P. A. Wood, J. Appl. Crystallogr., 2008, 41, 466-470.

35 Spartan $18^{\circ}$ (2018) Wavefunction, Inc., 18401 Von Karman Ave., Suite 370 Irvine, CA 92612 U.S.A.

36 (a) J.-D. Chai and M. Head-Gordon, J. Chem. Phys., 2008, 128 0841061-18410615. (b) J.-D. Chai and M. Head-Gordon, Phys. Chem. Chem. Phys., 2008, 10, 6615-6620.

37 (a) P. J. Hay and W.R. Wadt, J. Chem. Phys., 1985, 82, 270-283. (b) W. R. Wadt and P. J. Hay, J. Chem. Phys., 1985, 82, 284-298. (c) P. J. Hay, W. R. Wadt, J. Chem. Phys., 1985, 82, 299-310.

38. W. J. Hehre, R. Ditchfeld and J. A. Pople, J. Chem. Phys., 1972, 56, 2257-2261.

\section{Table of Contents Text}

Heterobi- and tetrametallic phosphoniocarbyne bridged complexes arise from the reactions of the terminal phosphoniocarbyne $\left[\mathrm{W}\left(\equiv \mathrm{CPMe}_{2} \mathrm{Ph}\right)(\mathrm{CO})_{2}\left(\mathrm{Tp}^{*}\right)\right] \mathrm{PF}_{6}$ with unsaturated metal centres.

\section{Table of Contents Graphic}

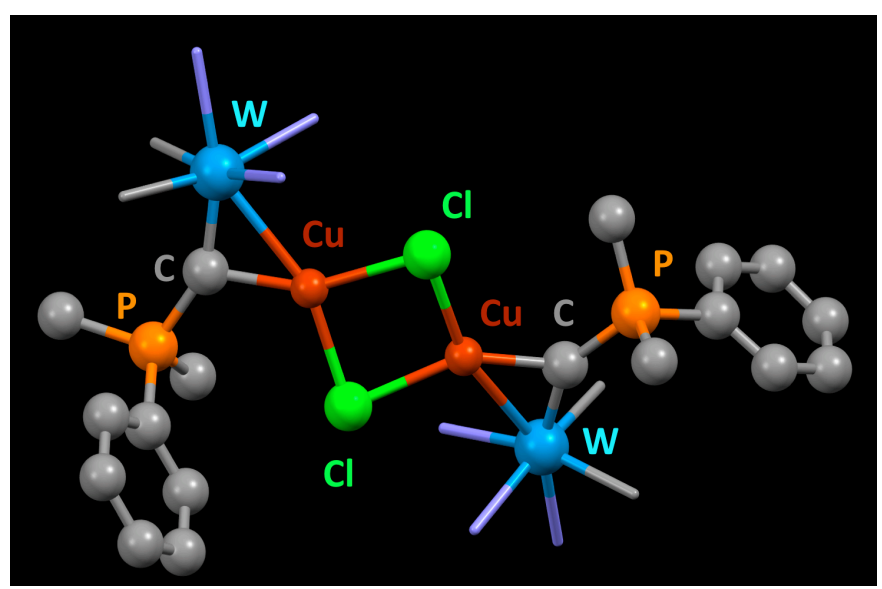

